\title{
Production of Organic Fertilizers from Rocket Seed (Eruca Sativa L.), Chicken Peat and Moringa Oleifera Leaves for Growing Linseed under Water Deficit Stress
}

\author{
Asif Ullah Khan ${ }^{1}\left(0\right.$, Faizan Ullah ${ }^{1, *}$, Naeem Khan ${ }^{2}$, Sultan Mehmood ${ }^{1}$, Shah Fahad ${ }^{3,4, *}$, Rahul Datta ${ }^{5}$, \\ Inam Irshad ${ }^{6}$, Subhan Danish ${ }^{7}$, Shah Saud ${ }^{8}$, Ibrahim A. Alaraidh ${ }^{9}$, Hayssam M. Ali ${ }^{9}$, Manzer H. Siddiqui ${ }^{9}$, \\ Zalan Alam Khan ${ }^{10}$, Shah Masud Khan ${ }^{11}$ and Ghulam Sabir Hussain ${ }^{12}$
}

Citation: Khan, A.U.; Ullah, F.; Khan N.; Mehmood, S.; Fahad, S.; Datta, R.; Irshad, I.; Danish, S.; Saud, S.; Alaraidh, I.A.; Ali, H.M.; et al. Production of Organic Fertilizers from Rocket Seed (Eruca Sativa L.), Chicken Peat and Moringa Oleifera Leaves for Growing Linseed under Water Deficit Stress. Sustainability 2021, 13, 59. https://doi.org/ $10.3390 /$ su13010059

Received: 12 November 2020 Accepted: 19 December 2020 Published: 23 December 2020

Publisher's Note: MDPI stays neutral with regard to jurisdictional clai$\mathrm{ms}$ in published maps and institutional affiliations.

Copyright: (C) 2020 by the authors. Licensee MDPI, Basel, Switzerland. This article is an open access article distributed under the terms and conditions of the Creative Commons Attribution (CC BY) license (https:// creativecommons.org/licenses/by/ $4.0 /)$.
1 Department of Botany, University of Science and Technology, Bannu 28100, Pakistan; asifullahkhan29@yahoo.com (A.U.K.); sultanwazir@outlook.com (S.M.)

2 Department of Agronomy, University of Florida, Gainesville, FI 32611, USA; naeemkhan@ufl.edu

3 Hainan Key Laboratory for Sustainable Utilization of Tropical Bioresource, College of Tropical Crops, Hainan University, Haikou 570228, China

4 Department of Agronomy, The University of Haripur, Haripur 22620, Pakistan

5 Department of Geology and Pedology, Faculty of Forestry and Wood Technology, Mendel University in Brno, Zemedelska 3, 61300 Brno, Czech Republic; rahulmedcure@gmail.com

6 Institute of Soil and Environmental Sciences, University of Agriculture Faisalabad, Punjab 38000, Pakistan; Inamirshad12@gmail.com

7 Department of Soil Science, Faculty of Agricultural Sciences and Technology, Bahauddin Zakariya University, Multan 60800, Pakistan; sd96850@gmail.com

8 Department of Horticulture, Northeast Agriculture University, Harbin 150030, China; saudhort@gmail.com

9 Department of Botany and Microbiology, College of Science, King Saud University,

Riyadh 11451, Saudi Arabia; ialaraidh@ksu.edu.sa (I.A.A.); hayhassan@ksu.edu.sa (H.M.A.); mhsiddiqui@ksu.edu.sa (M.H.S.)

10 Department of Civil Engineering, COMSATS University, Abbotabad 22010, Pakistan; zalanalamkhan@gmail.com

11 Department of Horticulture, The University of Haripur, Haripur 22620, Pakistan; drshahmasaudkhan@uoh.edu.pk

12 Department of Agronomy, Faculty of Agricultural Sciences and Technology, Bahauddin Zakariya University, Multan 60800, Pakistan; hussainsabirsia190@yahoo.com

* Correspondence: drfaizanwazir@gmail.com (F.U.); shahfahad80@yahoo.com or shahfahad@uoswabi.edu.pk (S.F.)

Abstract: Linseed is an important industrial crop cultivated for its edible seeds and fiber linen. Organic fertilizers have beneficial effects on soil properties and quality of crops. Therefore, we conducted two field experiments during 2018-2019 and 2019-2020 to determine the effect of organic fertilizers on soil fertility, yield and fiber quality of linseed varieties Roshni, BL1 and Chandni under low soil moisture conditions. We prepared organic fertilizers from seed cake of Eruca sativa, leaves of Moringa oleifera and chicken peat in various combinations by composting method. The various formulations of organic fertilizers included OF1(1 kg seed cake of Eruca sativa), OF2 (1 kg seed cake of Eruca sativa $+1 \mathrm{~kg}$ chicken peat), OF3 (1 kg seed cake of Eruca sativa $+0.5 \mathrm{~kg}$ chicken peat $+0.25 \mathrm{~kg}$ Moringa oliefera leaves) and OF4 (1 kg seed cake of Eruca sativa $+0.250 \mathrm{~kg}$ chicken peat $+0.5 \mathrm{~kg}$ Moringa oliefera leaves). Compositional analysis of organic fertilizers indicated that OF3 and OF4 had higher and may potentially sufficient quantities of NPK and organic matter. Both of these fertilizers significantly improved soil total N, available P, K, Zn and Fe contents. Growth response of linseed varieties to organic fertilizers was evaluated under water deficit stress $(40 \%$ field capacity of soil) at tillering stage for one month. Water stress had significantly adverse effects on plant height, production of tillers per plant, leaf relative water content (LRWC), number of capsules per plant, thousand seed weight, total seed yield, straw yield, fiber length and fiber weight of linseed varieties. However, the application of OF3 and OF4 significantly enhanced plant height, tillers production, LRWC, seed yield, straw yield, fiber length and fiber weight under water deficit stress. Water deficit stress also resulted in a significant increase in the content of phenolics of both the leaves and roots. For each measured quality parameter of linseed varieties, organic fertilizer treatments resulted in 
higher values than untreated and irrigated control. We concluded that organic fertilizers particularly OF3 and OF4 significantly improved soil fertility and minimized negative effect of water deficit stress on plant height, tillers production, LRWC, seed yield, straw yield, fiber length and fiber weight of linseed varieties.

Keywords: growth attributes; osmotic stress; phenolics; fiber quality; soil fertility; yield attributes

\section{Introduction}

Sustainable agricultural production is a major global issue. The application of chemical fertilizers to get higher crop yields is a popular practice throughout the world. Nitrogen and phosphorus fertilizers are extensively used by farmers to get higher crop yield. However, continuous application of chemical fertilizers results in a decline of soil fertility and yield of crops over time [1]. Frequent use of such fertilizers has undesirable effects on soil health, such as soil acidification, soil compactions, heavy metals accumulation and suppression of beneficial soil microbial flora [2]. In present days, policy makers and scientists are opining on the use of biological materials as alternative sources of nutrients to chemical fertilizers for improving soil fertility and yield of crops [3,4]. The reason is that organic farming results in quality food without having any harmful effect on the health of soil and consumers [5]. Organic fertilizers are used as alternative sources of nutrients to chemical fertilizers for sustainable agriculture [6].

Organic fertilizers are synthesized from animal manure, animal matter, vegetable matter and compost [7,8] are good sources of N, P, and K [9], improve soil fertility, and increase growth and yield of plants [3,10]. Organic fertilizer and plant growth-promoting rhizobacteria is an better alternative to mineral fertilizers [11-15]. Use of biostimulants also reduce the need for mineral fertilizers [16-18]. Foliar application of fertilizer and micronutrient could be better alternative of fast action $[19,20]$. For the production of organic fertilizers, biological materials are composted by the action of soil micro-biota. The compost thus produced has higher content of organic matter and nutrients required for better growth and establishment of crops [21]. The composted material when applied to soil improves soil properties and makes available the soil nutrients to plants at a higher rate resulting in healthy plants with higher seed yield [22].

It improves chemical, physical and biochemical properties of the soil and reduces nutrients leaching [23]. It also mitigates environmental imbalance which is caused by increasing $\mathrm{CO}_{2}$ in atmospheres. Organic fertilizers improve water holding capacity of soil and thus protect plants from conditions of water stress [24,25]. Organic fertilizers also improve microbial activity in soil and ease the cycling of nutrients in soil [26,27].

Water stress is among the most commonly occurring abiotic stresses adversely influencing growth and yield of many economically important plant species [28]. Water deficit stress decreases the content of photosynthetic pigments, decreases turgidity of leaves, causes damage to cell membranes and inhibits cell division in growing parts of plants $[29,30]$.

Flax, also called flaxseed or linseed, belongs to the family Linaceae and is cultivated for food, medicinal oil and fiber purposes [31]. Linseed oil is used industrially for making paints, polishes, inks, cosmetic products and biodiesel [32,33]. Linseed oil contains $38 \%$ to $42 \%$ linoleic acid which is highly beneficial for human beings and other animals [34]. Linseed fibers are much stronger than cotton fibers and used for making clothes, bed sheet and table linen [35]. However, its production is severely affected by low nitrogen $(\mathrm{N})$ and phosphorous (P) content of the soil [36]. Moreover, it has been reported that deficiency of water limited the growth, yield and fiber quality of linseed [37]. A large part of agriculture lands in Pakistan are arid and deficient in NPK. Organic fertilizers have potential to improve water holding potential and fertility of soil [3]. For this purpose, we prepared organic fertilizers having seed cake of Eruca sativa, Moringa oleifera leaves and 
chicken peat in different ratios and evaluated their effect on growth, seed yield and fiber value of linseed under water deficit conditions.

\section{Materials and Methods}

\subsection{Preparation of Organic Fertilizers}

Eruca sativa, Chicken peat and M. oleifera leaves were selected as organic materials due to their ease of availability and low cost. Seed cake was prepared by grinding the seeds of Eruca sativa in an electric grinder. For this purpose, oil was first extracted from seeds in petroleum ether $(20 \mathrm{~L})$ using a Soxhlet extractor. After oil extraction, the seed cake obtained was utilized for the production of organic fertilizers. The chicken peat was collected from poultry farms in District Bannu KP, Pakistan. The Moringa oleifera (M. oleifera) leaves (10 kg) were collected from 20 healthy trees and dried in shade for 2 weeks.

For the required amount of seed cake of Eruca sativa, chicken peat and M. oleifera leaves were put in plastic bags, moistened (70\%) and buried deep down in soil ( $1 \mathrm{~m}$ deep) in a moist field near a water body. After 45 days, the bags were opened and the composted material was dried in the sun. The material was again moistened up to $70 \%$ and buried in same holes for 15 days [22]. After 15 days, the composted material was collected and spread on to plastic sheets to re-dry. The organic fertilizers made were OF1—seed cake of Eruca sativa (1 kg), OF2—seed cake of Eruca sativa (1 kg) + chicken peat (1 kg), OF3—seed cake of Eruca sativa $(1 \mathrm{~kg})+$ chicken peat $(0.5 \mathrm{~kg})+$ Moringa oleifera leaves $(0.25 \mathrm{~kg})$ and OF4 - seed cake of Eruca sativa $(1 \mathrm{~kg})+$ chicken peat $(0.250 \mathrm{~kg})+$ Moringa oleifera leaves $(0.5 \mathrm{~kg})$.

\subsection{Physico-Chemical Analysis of Organic Fertilizers}

The organic matter content of organic fertilizers was determined by the method of Nelson and Sommers [38]. The K, Fe and Zn content in organic fertilizers was determined by wet digestion method using Nitric-Perchloric acid $\left(\mathrm{HNO}_{3}-\mathrm{HClO}_{4}\right)$ through atomic absorption spectrophotometer $[39,40]$. Phosphorus contents were determined by ammonium vanadomolybdate absorption spectrometry method [41]. Nitrogen content was determined by the Kjeldahl method [42].

\subsection{Assessment of Organic Fertilizers Potential on Growth Of Linseed}

Field experiments were carried out under natural conditions during linseed growing seasons of 2018-2019 and 2019-2020 in District Bannu KP, Pakistan. The total rainfall during linseed growing season of 2018-2019 was $284.7 \mathrm{~mm}$ whereas, total rainfall during linseed growing season of 2019-2020 was $227.4 \mathrm{~mm}$. The average monthly minimum and maximum temperature during $2018-2019$ was 11.02 and $24.07^{\circ} \mathrm{C}$ respectively. Similarly, average monthly minimum and maximum temperature during linseed growing season of 2019-2020 was 11.19 and $23.29^{\circ} \mathrm{C}$ respectively. The field soil was clay loam having $\mathrm{pH} 8.40$, EC $230 \mu \mathrm{S} \mathrm{cm}{ }^{-1}$, organic matter $0.69 \%$, total nitrogen $0.03 \%$, available phosphorus $4.02 \%$, available potassium $0.40 \%, \mathrm{Ca} / \mathrm{Mg} 9.5 \mathrm{meq} / \mathrm{L}$, carbonate $1.4 \mathrm{meq} / \mathrm{L}$ and bicarbonate $1.9 \mathrm{meq} / \mathrm{L}$. The soil fertility was also determined after two days of crop harvest [43-48].

Seeds of linseed varieties Roshni and Chandni were obtained from Ayub Agriculture Research Institute Faisalabad Pakistan. Local genotype BL1 of linseed cultivated in District Bannu was obtained from Agriculture Research Station Bannu, Pakistan. Uniform size seeds of linseed were selected and sterilized with $95 \%$ ethanol. The seeds were washed carefully with autoclaved distilled water and sown in the field at $30 \mathrm{~kg} / \mathrm{ha}$ [49].

The experiment was carried out as a split plot design, having factorial arrangements of the treatments in three replicates per treatment. Plots measuring $1 \times 1 \mathrm{~m}^{2}$, consisting of four rows each and $20 \mathrm{~cm}$ apart were used. The organic fertilizers were applied at $3000 \mathrm{~kg} / \mathrm{ha}$ two weeks before sowing of seeds in the field. Moreover, recommended doses of nitrogen $(80 \mathrm{~kg} / \mathrm{ha})$, phosphorus $(40 \mathrm{~kg} / \mathrm{ha})$ and potassium $(30 \mathrm{~kg} / \mathrm{ha})$ were applied through the broadcast method manually in the field before sowing of seeds. The sources of fertilizers were urea (for $\mathrm{N}$ ), diammonium phosphate (for $\mathrm{N}$ and $\mathrm{P}$ ) and potassium 
sulfate (for K) [50]. Water deficit stress was imposed by closing of water supply to plants up to $40 \%$ field capacity of soil at vegetative growth stage (60 DAS) for one month. Two irrigation regimes, control (normal irrigation as recommended for linseed crop 100\% soil field capacity) and water stress (skipped irrigations to maintain $40 \%$ soil field capacity), represented the main plots. Combination of three linseed varieties (Chandni, Roshni and BL1) and four organic fertilizers (OF1, OF2, OF3, and OF4) treatments $(0 \mathrm{~kg} / \mathrm{hectare}$ and $3000 \mathrm{~kg} /$ hectare) were randomly dispersed in the sub plots. At the end of the water stress period leaves were collected randomly from plants in all treatments and analyzed for the following parameters. Leaf relative water content (LRWC) was estimated according to the method of Gao [51] based on Equation (1).

LRWC $(\%)=$ Leaf fresh weight - Leaf dry weight/Leaf turgid weight - Leaf dry weight $\times 100$.

Method of Shen et al. [52] modified by Ma et al. [53] was considered for extraction of total phenolics content A $2 \mathrm{~g}$ tissue of root or leaf was extracted in acidified ( $1 \% \mathrm{HCL}$ ) methanol $(16 \mathrm{~mL})$ for one day and night at $25 \pm 01^{\circ} \mathrm{C}$. After centrifugation of the mixtures at $4000 \times g$ for $15 \mathrm{~min}$, a $500 \mu \mathrm{L}$ of supernatant was added with Folin Ciocalteu reagent $(5 \mathrm{~mL})$ and $4 \mathrm{~mL}$ of sodium carbonate solution $(7.5 \mathrm{~g} / 100 \mathrm{~mL})$. The mixtures were subjected to incubation for $120 \mathrm{~min}$ and their absorbance was measured at $765 \mathrm{~nm}$ (Spectrophotometer SP-300, Tokyo, Japan). Total phenolics content was stated as mg GAE/g fresh weight.

\subsection{Yield and Yield Related Parameters}

The plants in all treatments were supplied with water and allowed to grow to maturity. When the plants turned yellow and their capsules were mature, then they were analyzed for yield and quality of fiber. Plant height of randomly selected 10 plants/plot was measured using a measuring tape. Similarly, the number of tillers/plants of 10 randomly selected plants/plot were counted. The total number of capsules/plants was determined from counts on 10 plants/plots. The capsules were crushed and cleaned mechanically and the total number of seeds/capsules were estimated. The 1000 seed weight of 10 random plants/plot was determined using a digital balance. After the threshing seeds of all plants in each treatment were dried to $7 \%$ moisture content and their weight was determined. Total seed yield obtained per plot was converted to $\mathrm{kg} / \mathrm{ha}$. The total weight in grams of the air-dried straw of all plants without capsules in area of each plot was measured and the values were converted into $\mathrm{kg} / \mathrm{ha}$. Seed length and width was determined using a digital Vernier Caliper.

After harvesting, the straw was separated and put into stagnant water for four days. Then it was washed with water after completely retting and drying in the sun. The fiber was removed by means of scotching [35]. Fiber length was determined by common measuring tape whereas, fiber weight was determined using a digital balance.

\subsection{Statistical Analysis}

The data of two years were combined and analyzed by two-way analysis of variance. The means of treatments and control were compared by LSD test [54]. Pearson correlation was determined for growth and yield parameters.

\section{Results}

\subsection{Compositional Analyses of Organic Fertilizers}

Our results showed that organic fertilizers have balanced composition with respect to NPK values (Table 1). The N content of organic fertilizers recorded for OF1 were $2.57 \%$, OF2 $3.20 \%$, OF3 2.75\% and OF4 2.74\% respectively. Similarly, P content found in organic fertilizers was OF $10.71 \%$, OF $2.46 \%$, OF3 $0.81 \%$ and OF $4.84 \%$. The $\mathrm{K}$, organic matter and Fe content was higher in OF3 than OF1, OF2 and OF4. The EC value recorded was highest for OF2 $13.40 \mathrm{mS} / \mathrm{cm}$ and lowest for OF1 $7.93 \mathrm{mS} / \mathrm{cm}$. The Fe value for various formulations of organic fertilizers was OF1 $3422.3 \mathrm{mg} / \mathrm{kg}$, OF2 $2893.3 \mathrm{mg} / \mathrm{kg}$, OF3 $4118.7 \mathrm{mg} / \mathrm{kg}$ and OF4 $3485.0 \mathrm{mg} / \mathrm{kg}$ respectively. 
Table 1. Characterization of organic fertilizers.

\begin{tabular}{|c|c|c|c|c|c|c|c|c|}
\hline $\begin{array}{l}\text { Organic } \\
\text { Fertilizer }\end{array}$ & $\mathrm{pH}$ & $\mathrm{EC}(\mathrm{mS} / \mathrm{cm})$ & $\begin{array}{c}\mathrm{N} \\
(\%)\end{array}$ & $\begin{array}{c}P \\
(\%)\end{array}$ & $\begin{array}{c}K \\
(\%)\end{array}$ & OM (\%) & $\begin{array}{c}\mathrm{Zn} \\
(\mathrm{mg} / \mathrm{kg})\end{array}$ & $\begin{array}{c}\mathrm{Fe} \\
(\mathrm{mg} / \mathrm{kg})\end{array}$ \\
\hline OF1 & $4.78 \pm 0.10^{c}$ & $7.93 \pm 0.08^{d}$ & $2.57 \pm 0.13^{b}$ & $0.71 \pm 0.10^{\mathrm{ab}}$ & $8.21 \pm 0.07^{c}$ & $2.83 \pm 0.07^{\mathrm{d}}$ & $230.00 \pm 15.27^{c}$ & $3422.3 \pm 12.71^{c}$ \\
\hline OF2 & $6.50 \pm 0.15^{\mathrm{a}}$ & $13.40 \pm 0.12^{\mathrm{a}}$ & $3.20 \pm 0.11^{\mathrm{a}}$ & $0.46 \pm 0.04^{\mathrm{b}}$ & $11.78 \pm 0.10^{b}$ & $4.10 \pm 0.11^{\mathrm{c}}$ & $372.00 \pm 9.64^{\mathrm{a}}$ & $2893.3 \pm 7.50^{d}$ \\
\hline OF3 & $6.22 \pm 0.13^{\mathrm{ab}}$ & $12.90 \pm 0.11^{b}$ & $2.75 \pm 0.08^{b}$ & $0.81 \pm 0.09^{a}$ & $12.43 \pm 0.10^{a}$ & $10.88 \pm 0.11^{\mathrm{a}}$ & $322.33 \pm 12.46^{b}$ & $4118.7 \pm 11.05^{\mathrm{a}}$ \\
\hline OF4 & $5.93 \pm 0.14^{b}$ & $10.80 \pm 0.08^{c}$ & $2.74 \pm 0.16^{b}$ & $0.84 \pm 0.04^{a}$ & $11.58 \pm 0.11^{b}$ & $5.50 \pm 0.17^{b}$ & $324.00 \pm 6.65^{b}$ & $3485.0 \pm 11.21^{b}$ \\
\hline
\end{tabular}

Note: ${ }^{a}, a b, b, c, d$ means followed by different letters in each column are significantly differ-ent from each other at $\alpha=0.05$. OF1-organic fertilizer 1 ( $1 \mathrm{~kg}$ seed cake of Eruca sativa), OF2-organic fertilizer 2 (1 kg seed cake of Eruca sativa + $1 \mathrm{~kg}$ Chicken peat), OF3-organic fertilizer 3 ( $1 \mathrm{~kg}$ seed cake of Eruca sativa $+0.5 \mathrm{~kg}$ chicken peat $+0.25 \mathrm{~kg}$ Moringa oleifera leaves), OF4-organic fertilizer 4 (1 kg seed cake of Eruca sativa $+0.250 \mathrm{~kg}$ chicken peat $+0.5 \mathrm{~kg}$ Moringa oleifera leaves).

\subsection{Effects of Organic Fertilizers on Soil Fertility Status}

We recorded improvement in soil fertility related parameters after the application of organic fertilizers (Table 2). The treatments OF3 and OF4 were more responsive and resulted in a higher soil N, P, K, Zn and Fe contents. Maximum value of organic matter content was recorded in field soil amended with OF3. Soil pH and EC was significantly affected by organic fertilizers. The highest EC value $\left(280 \mu \mathrm{S} \mathrm{cm}^{-1}\right)$ was recorded for treatment OF2 over the control $\left(230 \mu \mathrm{S} \mathrm{cm}{ }^{-1}\right)$ whereas, OF4 amended soil had lowest EC value $\left(240 \mu \mathrm{S} \mathrm{cm}^{-1}\right)$. The soil $\mathrm{pH}$ was significantly decreased due to application of OF3 and OF4.

Table 2. Effect of organic fertilizers on soil fertility status.

\begin{tabular}{|c|c|c|c|c|c|c|c|c|}
\hline $\begin{array}{c}\text { Organic } \\
\text { Fertilizers }\end{array}$ & $\begin{array}{c}\text { Total N } \\
(\%)\end{array}$ & $\begin{array}{c}\text { Available } P \\
(\%)\end{array}$ & $\begin{array}{c}\text { Available K } \\
\left(\mathrm{mg} \mathrm{kg}^{-1}\right)\end{array}$ & $\begin{array}{c}\text { Organic } \\
\text { Matter (\%) }\end{array}$ & $\begin{array}{c}\mathrm{Zn} \\
\left(\mathrm{mg} \mathrm{kg}^{-1)}\right.\end{array}$ & $\begin{array}{c}\mathrm{Fe} \\
\left(\mathrm{mg} \mathrm{kg}^{-1)}\right.\end{array}$ & Soil pH & $\begin{array}{l}\text { Soil EC } \\
\left(\mu \mathrm{cm}^{-1}\right)\end{array}$ \\
\hline Control & $0.0343 \pm 0.00^{c}$ & $4.00 \pm 0.00^{c}$ & $150.06 \pm 0.18^{\mathrm{e}}$ & $0.69 \pm 0.04^{d}$ & $0.97 \pm 0.02^{d}$ & $0.80 \pm 0.03^{\mathrm{e}}$ & $8.40 \pm 0.05^{a}$ & $230 \pm 1.09^{c}$ \\
\hline OF1 & $0.0387 \pm 0.00^{b}$ & $6.03 \pm 0.03^{a}$ & $155.13 \pm 0.24^{\mathrm{d}}$ & $0.79 \pm 0.01^{\mathrm{c}}$ & $1.05 \pm 0.05^{\mathrm{d}}$ & $0.95 \pm 0.03^{d}$ & $7.80 \pm 0.05^{c}$ & $250 \pm 2.00^{b}$ \\
\hline OF2 & $0.0413 \pm 0.00^{\mathrm{ab}}$ & $5.10 \pm 0.05^{b}$ & $169.98 \pm 0.18^{c}$ & $0.82 \pm 0.09^{b}$ & $1.32 \pm 0.08^{c}$ & $1.25 \pm 0.07^{c}$ & $8.10 \pm 0.05^{b}$ & $280 \pm 1.01^{a}$ \\
\hline OF3 & $0.0433 \pm 0.00^{\mathrm{a}}$ & $5.13 \pm 0.08^{b}$ & $190.03 \pm 0.43^{b}$ & $0.86 \pm 0.01^{a}$ & $2.18 \pm 0.09^{a}$ & $2.45 \pm 0.06^{b}$ & $7.80 \pm 0.05^{c}$ & $270 \pm 2.00^{a}$ \\
\hline OF4 & $0.0403 \pm 0.00^{\mathrm{ab}}$ & $6.00 \pm 0.00^{\mathrm{a}}$ & $224.93 \pm 0.23^{a}$ & $0.79 \pm 0.00^{c}$ & $1.49 \pm 0.08^{b}$ & $2.75 \pm 0.08^{a}$ & $7.80 \pm 0.05^{c}$ & $240 \pm 2.03^{b c}$ \\
\hline
\end{tabular}

Note: ${ }^{\mathrm{a}}, \mathrm{ab}, \mathrm{b}, \mathrm{bc}, \mathrm{c}, \mathrm{d}, \mathrm{e}$ means followed by different letters in each column are significantly differ-ent from each other at $\alpha=0.05$.

\subsection{Organic Fertilizers Effect on Growth of Linseed}

Our data showed that water deficit stress decreased plant height of linseed varieties (Figure 1). The percent decrease in plant height due to water deficit stress was higher in Chandni (18.01\%) than Roshni (13.56\%) and BL1 (12.37\%) as compared with their respective untreated and irrigated control. In non-stress conditions all the treatments of organic fertilizers significantly improved plant height of linseed varieties. All the three varieties of linseed showed greater response to OF3 and OF4. In response to OF3 and OF4 applications, Roshni showed $8.52 \%$ increase in plant height than its untreated control. Similarly, BL1 showed $12.6 \%$ increase in plant height due to OF4 application over its untreated and irrigated control. In Chandni treatments OF3 and OF4 showed $10.48 \%$ and $9.75 \%$ increase in plant height over untreated and irrigated control. The percent decrease in plant height due to water deficit stress was completely overcome by the application of organic fertilizers; however, OF3 and OF4 were more effective.

Production of tillers per plant was significantly affected by water deficit stress in all the three varieties of linseed; however, the percent decrease was more significant in Chandni $(40 \%)$ than BL1 (38.33\%) and Roshni (37.52\%). In non-stress conditions organic fertilizers significantly improved tillers production per plant of linseed varieties (Figure 2). Of the three varieties Roshni was more responsive to OF4; whereas BL1 and Chandni showed greater response to OF2 and OF3. The water stress induced decrease in tillers production was significantly overcome by the application of organic fertilizers. Under water deficit stress, the positive response of Roshni and Chandni was more significant to OF3 and OF4; whereas BL1 was highly responsive to OF1, OF2 and OF4. 


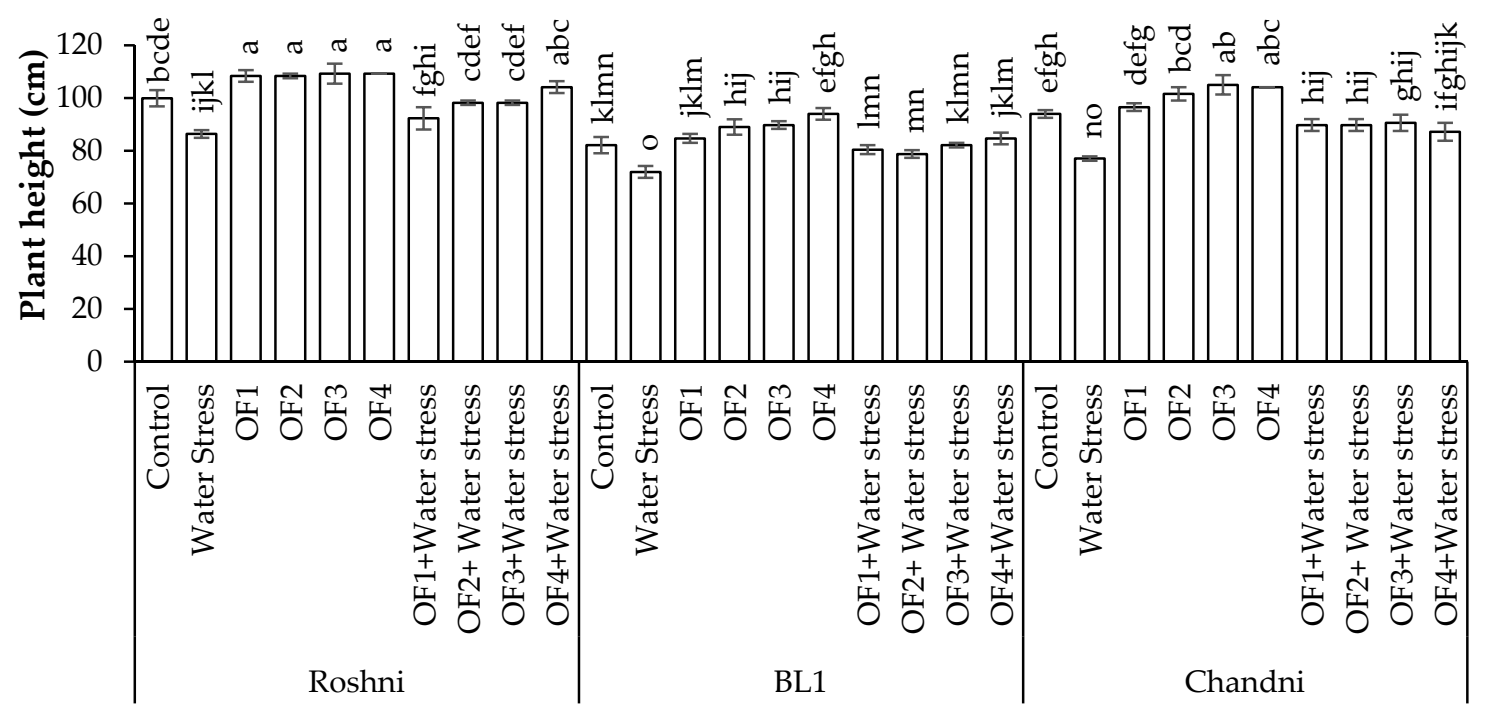

Treatments

Figure 1. Effect of organic fertilizers on plant height of linseed under water stress conditions. Due to non-significant variations in two years data, we pooled the data together. The different letters above the data columns indicate significant differences among the treatments. OF1-organic fertilizer 1 (1 kg seed cake of Eruca sativa), OF2-organic fertilizer 2 (1 kg seed cake of Eruca sativa $+1 \mathrm{~kg}$ Chicken peat), OF3-organic fertilizer 3 (1 kg seed cake of Eruca sativa $+0.5 \mathrm{~kg}$ Chicken peat $+0.25 \mathrm{~kg}$ Moringa oleifera leaves), OF4—organic fertilizer 4 (1 kg seed cake of Eruca sativa $+0.250 \mathrm{~kg}$ Chicken peat $+0.5 \mathrm{~kg}$ Moringa oleifera leaves).

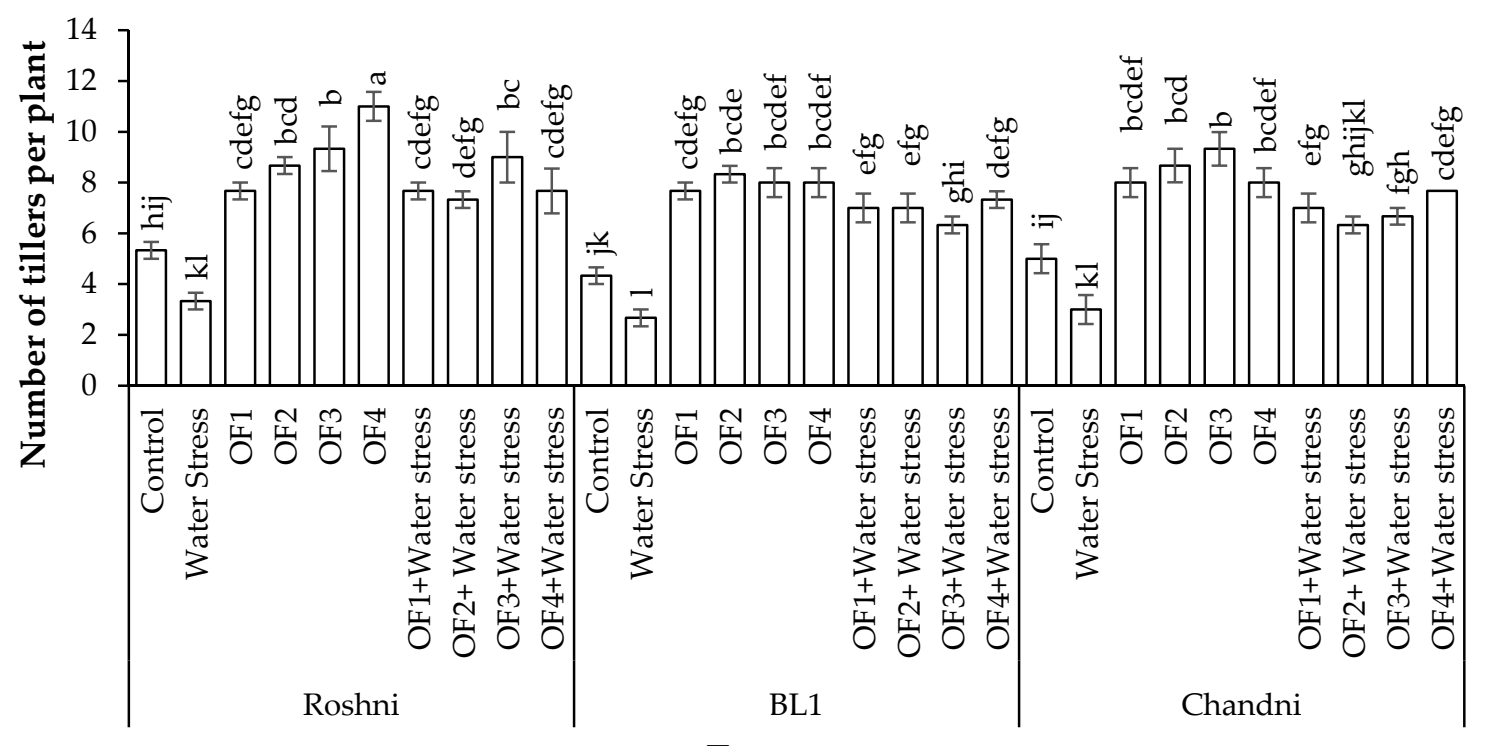

Treatments

Figure 2. Effect of organic fertilizers on number of tillers per plant of linseed under water stress conditions. Due to non-significant variations in two years data, we pooled the data together. The different letters above the data columns indicate significant differences among the treatments. OF1—organic fertilizer 1 (1 kg seed cake of Eruca sativa), OF2—organic fertilizer 2 (1 kg seed cake of Eruca sativa $+1 \mathrm{~kg}$ chicken peat), OF3—organic fertilizer 3 (1 kg seed cake of Eruca sativa $+0.5 \mathrm{~kg}$ chicken peat $+0.25 \mathrm{~kg}$ Moringa oleifera leaves), OF4—organic fertilizer 4 (1 kg seed cake of Eruca sativa $+0.250 \mathrm{~kg}$ chicken peat $+0.5 \mathrm{~kg}$ Moringa oleifera leaves).

Leaf relative water content (LRWC) of linseed varieties was negatively affected by water deficit stress (Figure 3) and the BL1 was more susceptible (12.84\%) than Chandni $(5.37 \%)$ and Roshni (1.95\%) as compared with their respective untreated and irrigated controls. Under normal irrigated conditions, all the formulations of organic fertilizer did 
not affect LRWC. However, the treatments were more effective under stress conditions and significantly overcome the water stress induced decrease in LRWC.

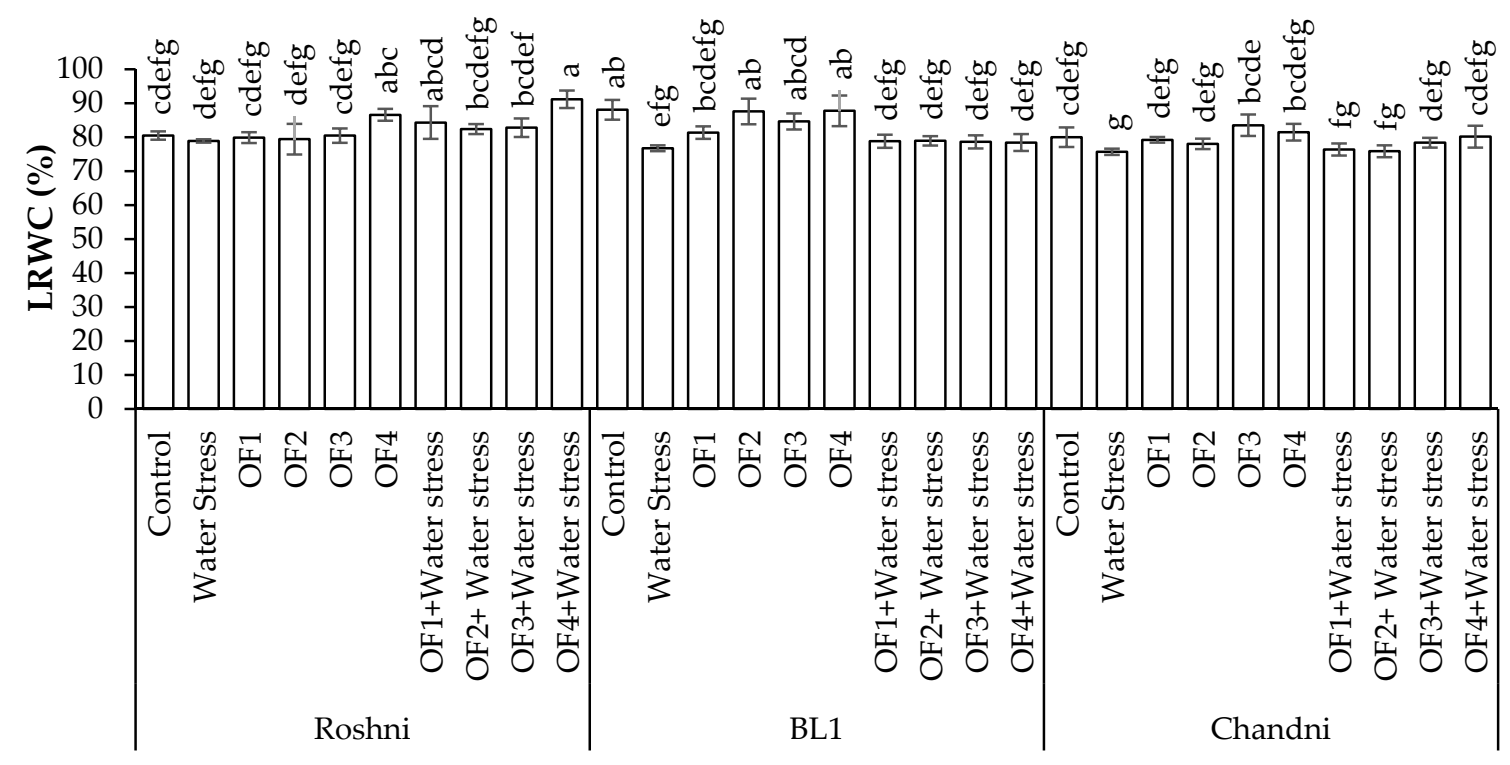

Treatments

Figure 3. Effect of organic fertilizers on leaf relative water content of linseed under water stress conditions. Due to non-significant variations in two years data, we pooled the data together. The different letters above the data columns indicate significant differences among the treatments. OF1—organic fertilizer 1 (1 kg seed cake of Eruca sativa), OF2—organic fertilizer 2 ( $1 \mathrm{~kg}$ seed cake of Eruca sativa $+1 \mathrm{~kg}$ chicken peat), OF3-organic fertilizer 3 (1 kg seed cake of Eruca sativa $+0.5 \mathrm{~kg}$ chicken peat $+0.25 \mathrm{~kg}$ Moringa oleifera leaves), OF4—organic fertilizer 4 (1 kg seed cake of Eruca sativa + $0.250 \mathrm{~kg}$ chicken peat $+0.5 \mathrm{~kg}$ Moringa oleifera leaves).

Water deficit stress resulted in a significant increase in root phenolics content as compared to untreated and irrigated control (Figure 4). The water deficit stress enhanced the root phenolics content of Roshni, BL1 and Chandni by $37.30 \%, 28.2 \%$ and $36.85 \%$ respectively as compared with their respective untreated and irrigated controls. In nonstress conditions organic fertilizers boosted production of phenolics in roots; however, maximum phenolics content was recorded for treatment OF4. In terms of phenolics content Roshni showed greater response to applied fertilizers than that of BL1 and Chandni. The treatment OF4 + water stress has significantly more phenolics in roots than any other treatment.

Similarly, significant increase was observed in the leaf phenolics contents of all three used linseed varieties (Figure 5). Percent increase in the phenolics content was higher in leaves of Roshni (44.47\%) followed by Chandni (35.94\%) and BL1 (35.28\%) as compared with their respective untreated and irrigated control. In a non-stress environment organic fertilizer treatment showed positive effect on the content of leaf phenolics; however, higher phenolics content was recorded in the leaves of plants treated with OF4. Under water stress conditions, the beneficial effects of organic fertilizers on phenolics content were more pronounced than under non-stress conditions. Significantly higher content of phenolics was recorded for treatment OF4 applied under water stress conditions. 


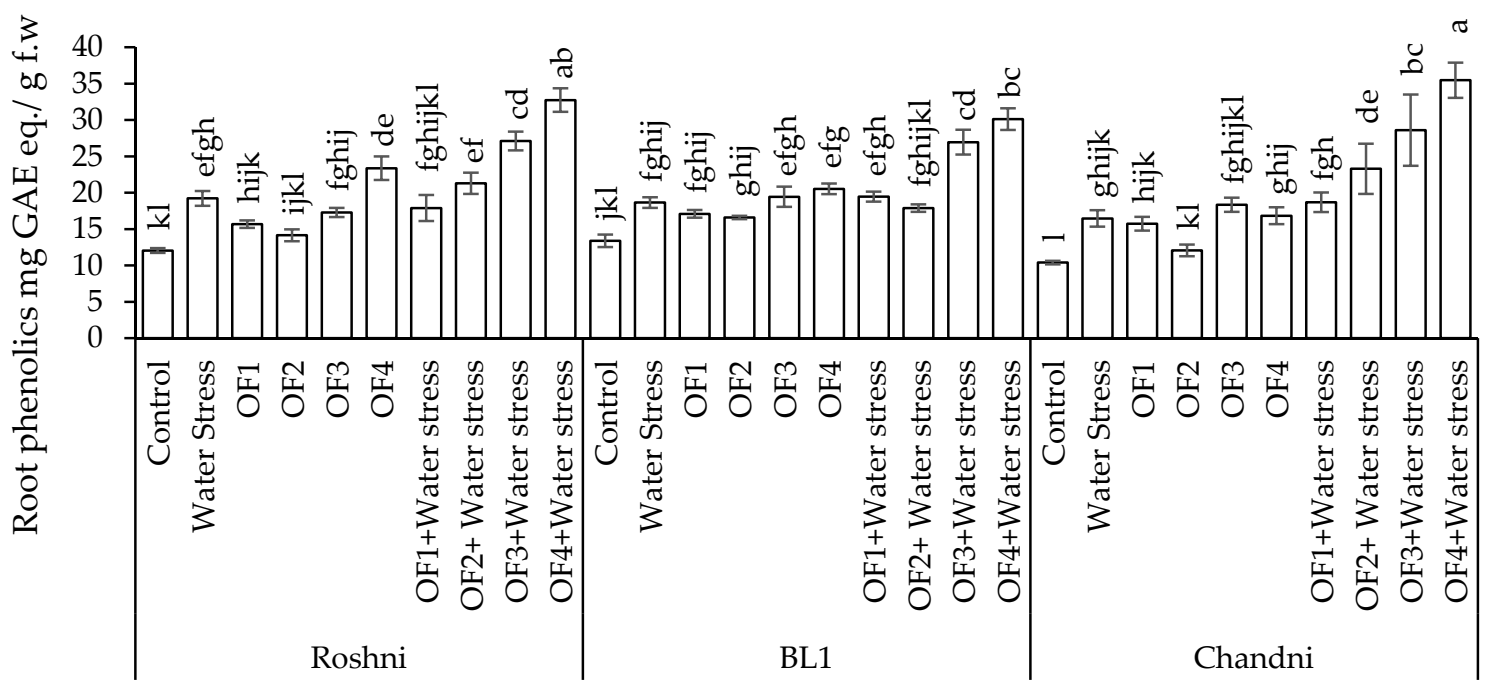

Treatments

Figure 4. Effect of organic fertilizers on root phenolics of linseed under water stress conditions. Due to non-significant variations in two years data, we pooled the data together. The different letters above the data columns indicate significant differences among the treatments. OF1—organic fertilizer 1 (1 kg seed cake of Eruca sativa), OF2—organic fertilizer 2 (1 kg seed cake of Eruca sativa $+1 \mathrm{~kg}$ chicken peat), OF3-organic fertilizer 3 (1 kg seed cake of Eruca sativa $+0.5 \mathrm{~kg}$ chicken peat $+0.25 \mathrm{~kg}$ Moringa oleifera leaves), OF4—organic fertilizer $4(1 \mathrm{~kg}$ seed cake of Eruca sativa $+0.250 \mathrm{~kg}$ chicken peat $+0.5 \mathrm{~kg}$ Moringa oleifera leaves).

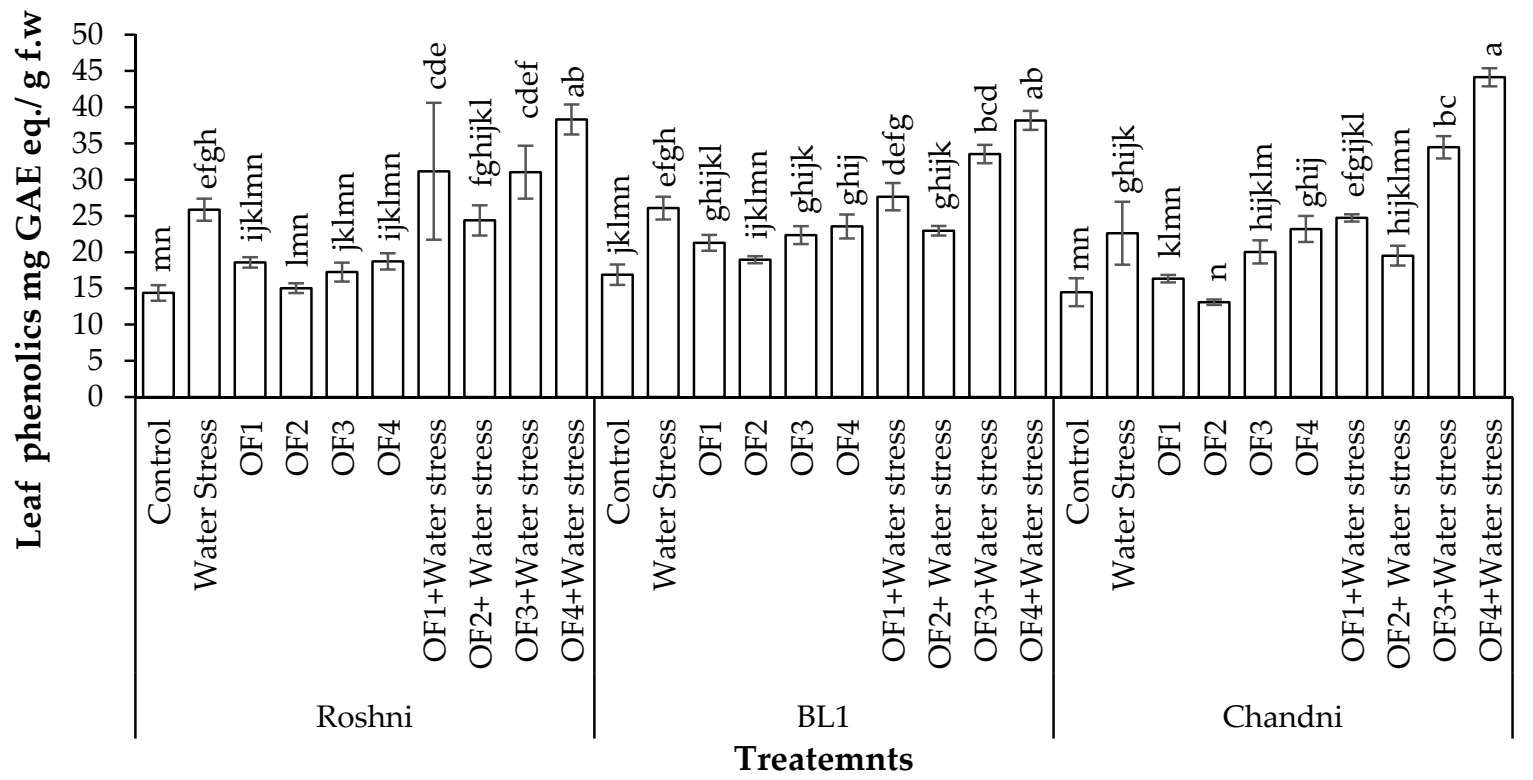

Figure 5. Effect of organic fertilizer on leaf phenolics content of linseed under water stress conditions. Due to non-significant variations in two years data, we pooled the data together. The different letters above the data columns indicate significant differences among the treatments. OF1—organic fertilizer 1 (1 kg seed cake of Eruca sativa), OF2—organic fertilizer 2 (1 kg seed cake of Eruca sativa $+1 \mathrm{~kg}$ chicken peat), OF3-organic fertilizer 3 (1 kg seed cake of Eruca sativa $+0.5 \mathrm{~kg}$ chicken peat $+0.25 \mathrm{~kg}$ Moringa oleifera leaves), OF4—organic fertilizer 4 (1 kg seed cake of Eruca sativa $+0.250 \mathrm{~kg}$ chicken peat $+0.5 \mathrm{~kg}$ Moringa oleifera leaves).

Our data revealed that yield parameters of linseed like number of capsules/plant, number of seeds/capsule, seed length and width, 1000 seed weight and total seed yield was decreased by water shortage in all the three varieties (Figures 6-11). In non-stress conditions, the soil amendment with organic fertilizers showed pronounced effects on total seed yield. Superior values of seed weight and total seed yield were obtained for 
treatments supplemented with OF3 and OF4. All the treatments of organic fertilizers decreased the adverse effects of water deficit stress on yield parameters. However, most influential organic fertilizers were OF3 and OF4 under water deficit conditions.

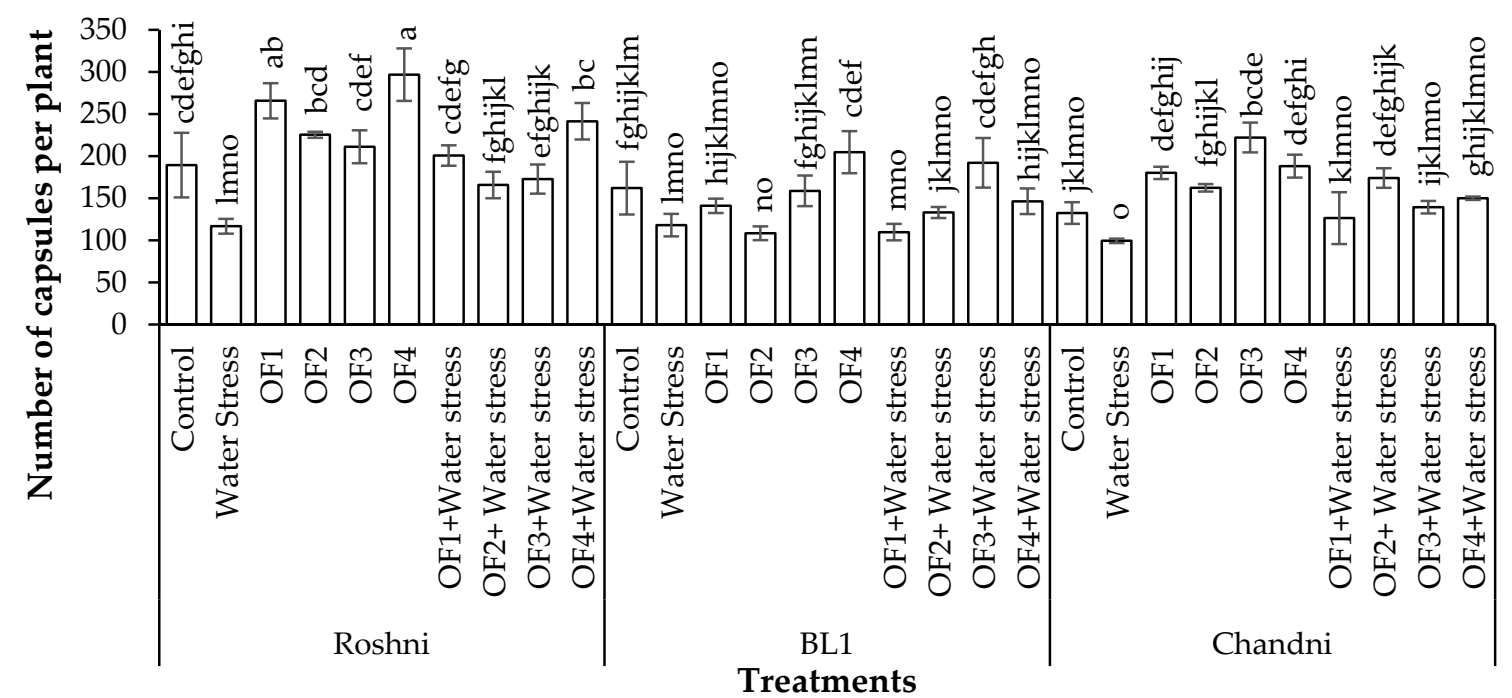

Figure 6. Effect of organic fertilizers on number of capsules per plant of linseed under water stress conditions. Due to non-significant variations in two years data, we pooled the data together. The different letters above the data columns indicate significant differences among the treatments. OF1—organic fertilizer 1 (1 kg seed cake of Eruca sativa), OF2—organic fertilizer 2 ( $1 \mathrm{~kg}$ seed cake of Eruca sativa $+1 \mathrm{~kg}$ chicken peat), OF3—organic fertilizer 3 ( $1 \mathrm{~kg}$ seed cake of Eruca sativa $+0.5 \mathrm{~kg}$ chicken peat $+0.25 \mathrm{~kg}$ Moringa oleifera leaves), OF4—organic fertilizer 4 (1 kg seed cake of Eruca sativa $+0.250 \mathrm{~kg}$ chicken peat $+0.5 \mathrm{~kg}$ Moringa oleifera leaves).

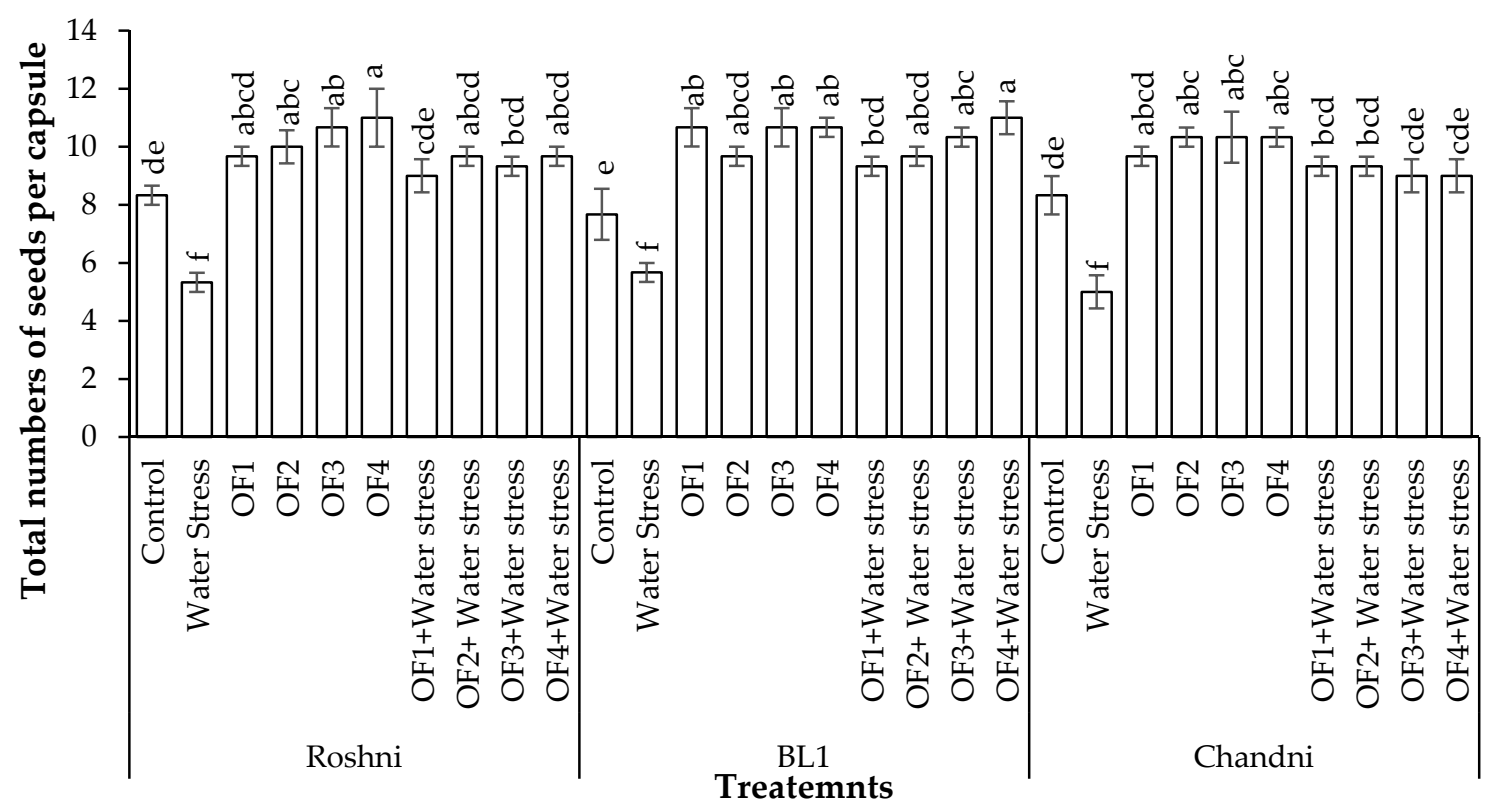

Figure 7. Effect of organic fertilizers on total numbers of seeds per capsule of linseed under water stress conditions. Due to non-significant variations in two years data, we pooled the data together. The different letters above the data columns indicate significant differences among the treatments. OF1—organic fertilizer 1 (1 kg seed cake of Eruca sativa), OF2—organic fertilizer 2 ( $1 \mathrm{~kg}$ seed cake of Eruca sativa $+1 \mathrm{~kg}$ chicken peat), OF3-organic fertilizer 3 (1 kg seed cake of Eruca sativa $+0.5 \mathrm{~kg}$ chicken peat $+0.25 \mathrm{~kg}$ Moringa oleifera leaves), OF4—organic fertilizer 4 (1 kg seed cake of Eruca sativa $+0.250 \mathrm{~kg}$ chicken peat $+0.5 \mathrm{~kg}$ Moringa oleifera leaves). 




Figure 8. Effect of organic fertilizers on seed length of linseed under water stress conditions. Due to non-significant variations in two years data, we pooled the data together. The different letters above the data columns indicate significant differences among the treatments. OF1—organic fertilizer 1 (1 kg seed cake of Eruca sativa), OF2—organic fertilizer 2 (1 kg seed cake of Eruca sativa $+1 \mathrm{~kg}$ chicken peat), OF3-organic fertilizer 3 (1 kg seed cake of Eruca sativa $+0.5 \mathrm{~kg}$ chicken peat $+0.25 \mathrm{~kg}$ Moringa oleifera leaves), OF4—organic fertilizer $4(1 \mathrm{~kg}$ seed cake of Eruca sativa $+0.250 \mathrm{~kg}$ chicken peat $+0.5 \mathrm{~kg}$ Moringa oleifera leaves).

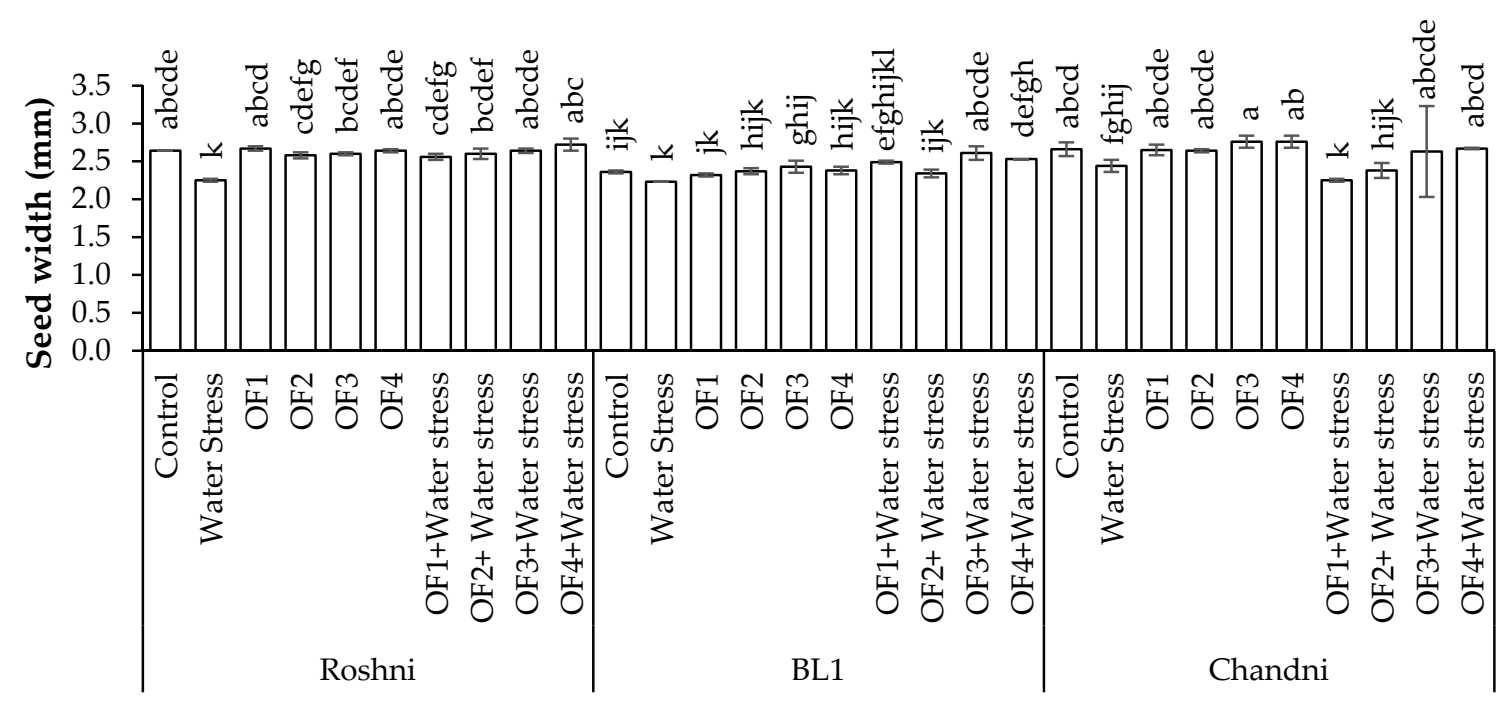

Treatments

Figure 9. Effect of organic fertilizers on seed width of linseed under water stress conditions. Due to non-significant variations in two years data, we pooled the data together. The different letters above the data columns indicate significant differences among the treatments. OF1—organic fertilizer 1 (1 kg seed cake of Eruca sativa), OF2—organic fertilizer 2 (1 kg seed cake of Eruca sativa $+1 \mathrm{~kg}$ chicken peat), OF3-organic fertilizer 3 (1 kg seed cake of Eruca sativa $+0.5 \mathrm{~kg}$ chicken peat $+0.25 \mathrm{~kg}$ Moringa oleifera leaves), OF4—organic fertilizer 4 (1 kg seed cake of Eruca sativa $+0.250 \mathrm{~kg}$ chicken peat $+0.5 \mathrm{~kg}$ Moringa oleifera leaves). 


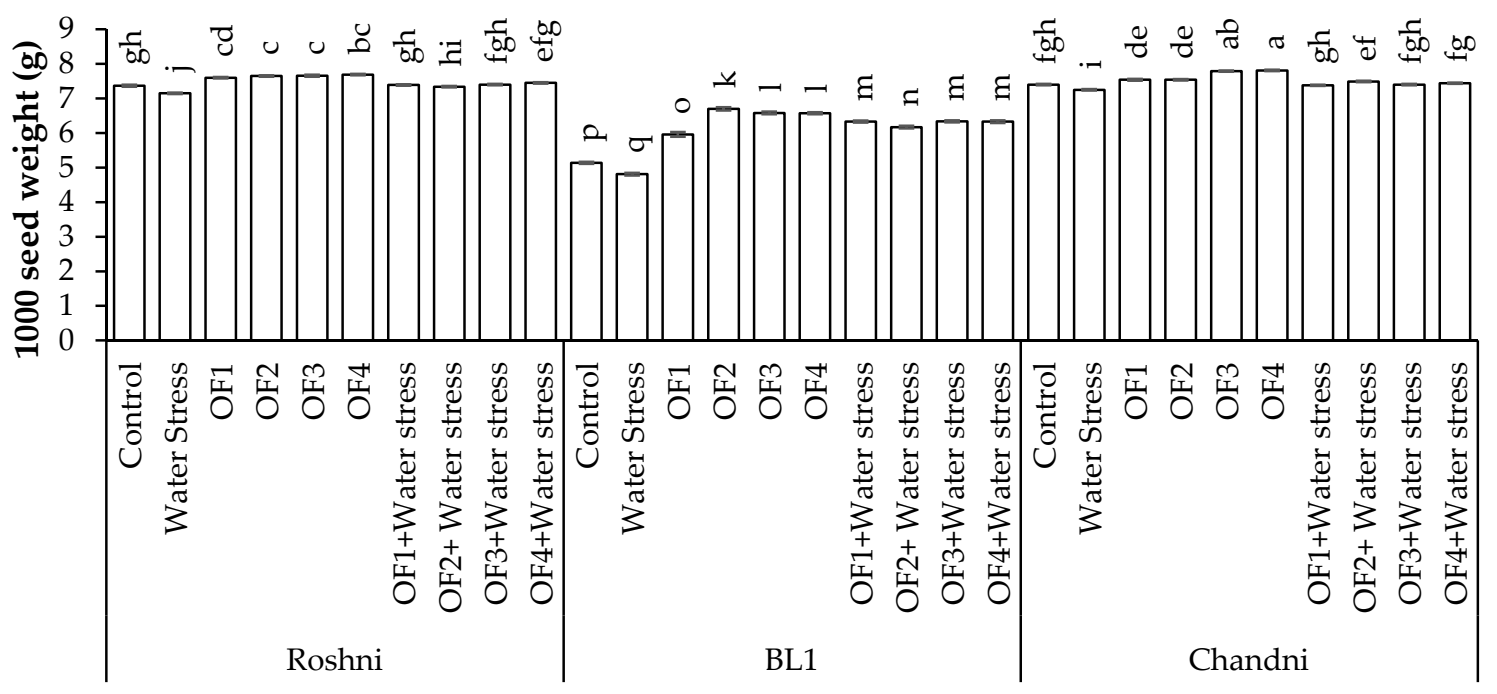

Treatments

Figure 10. Effect of organic fertilizers on 1000 seed weight of linseed under water stress conditions. Due to non-significant variations in two years data, we pooled the data together. The different letters above the data columns indicate significant differences among the treatments. OF1—organic fertilizer 1 (1 kg seed cake of Eruca sativa), OF2—organic fertilizer 2 (1 kg seed cake of Eruca sativa $+1 \mathrm{~kg}$ chicken peat), OF3-organic fertilizer 3 (1 kg seed cake of Eruca sativa $+0.5 \mathrm{~kg}$ chicken peat $+0.25 \mathrm{~kg}$ Moringa oleifera leaves), OF4—organic fertilizer 4 (1 kg seed cake of Eruca sativa $+0.250 \mathrm{~kg}$ chicken peat $+0.5 \mathrm{~kg}$ Moringa oleifera leaves).

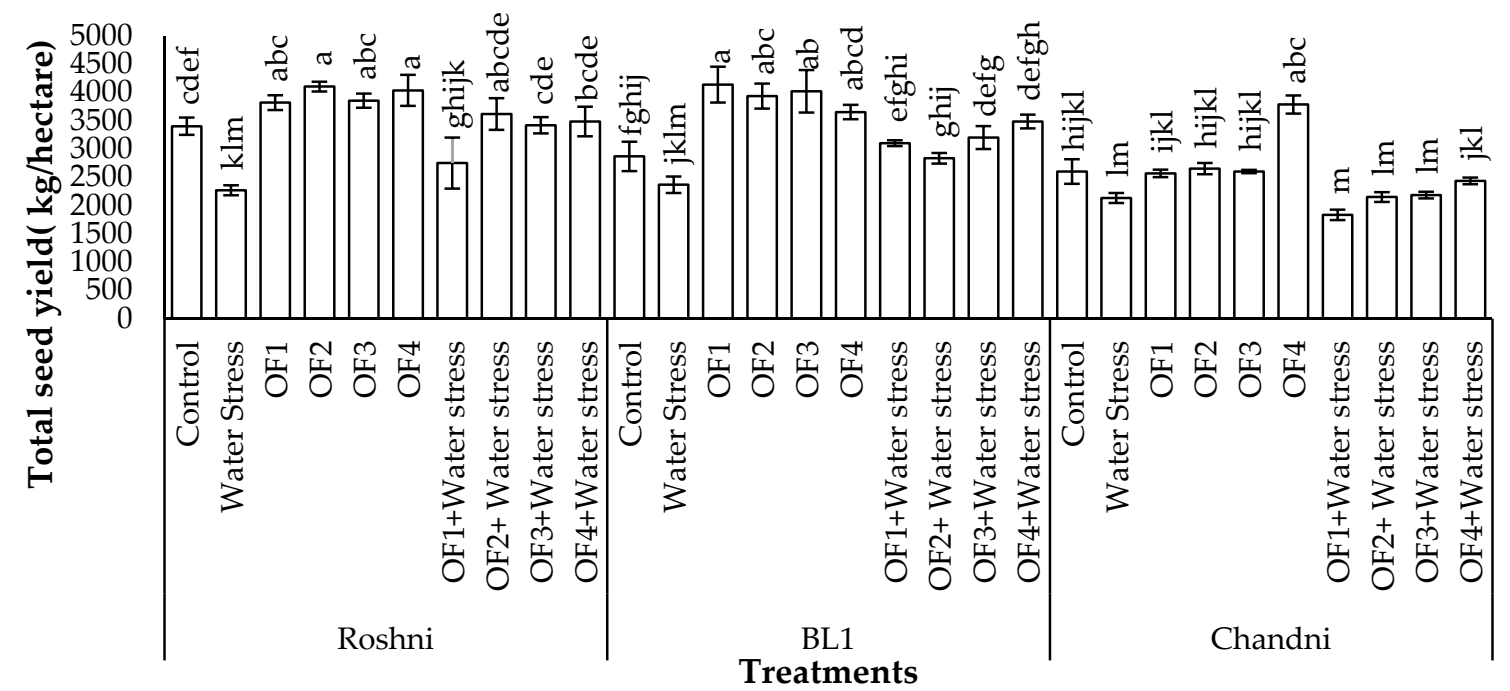

Figure 11. Effect of organic fertilizers on total seed yield of linseed under water stress conditions. Due to non-significant variations in two years data, we pooled the data together. The different letters above the data columns indicate significant differences among the treatments. OF1—organic fertilizer 1 (1 kg seed cake of Eruca sativa), OF2—organic fertilizer 2 (1 kg seed cake of Eruca sativa $+1 \mathrm{~kg}$ chicken peat), OF3-organic fertilizer 3 (1 kg seed cake of Eruca sativa $+0.5 \mathrm{~kg}$ chicken peat $+0.25 \mathrm{~kg}$ Moringa oleifera leaves), OF4—organic fertilizer 4 (1 $\mathrm{kg}$ seed cake of Eruca sativa $+0.250 \mathrm{~kg}$ chicken peat $+0.5 \mathrm{~kg}$ Moringa oleifera leaves).

Water stress significantly decreased straw yield of all the three varieties of linseed (Figure 12). Percent decrease in straw yield due to water deficit stress was higher in Roshni $(24.88 \%)$ than BL1 $(23.33 \%)$ and Chandni $(22.56 \%)$ as compared with their respective untreated and irrigated control. In non-stressed conditions, the application of OF3 and OF4 was superior to that of OF1 and OF2 and resulted in a higher straw yield. Among the four used organic fertilizers, OF4 was more promising in the alleviation of adverse effects of water deficiency on the straw yield. 


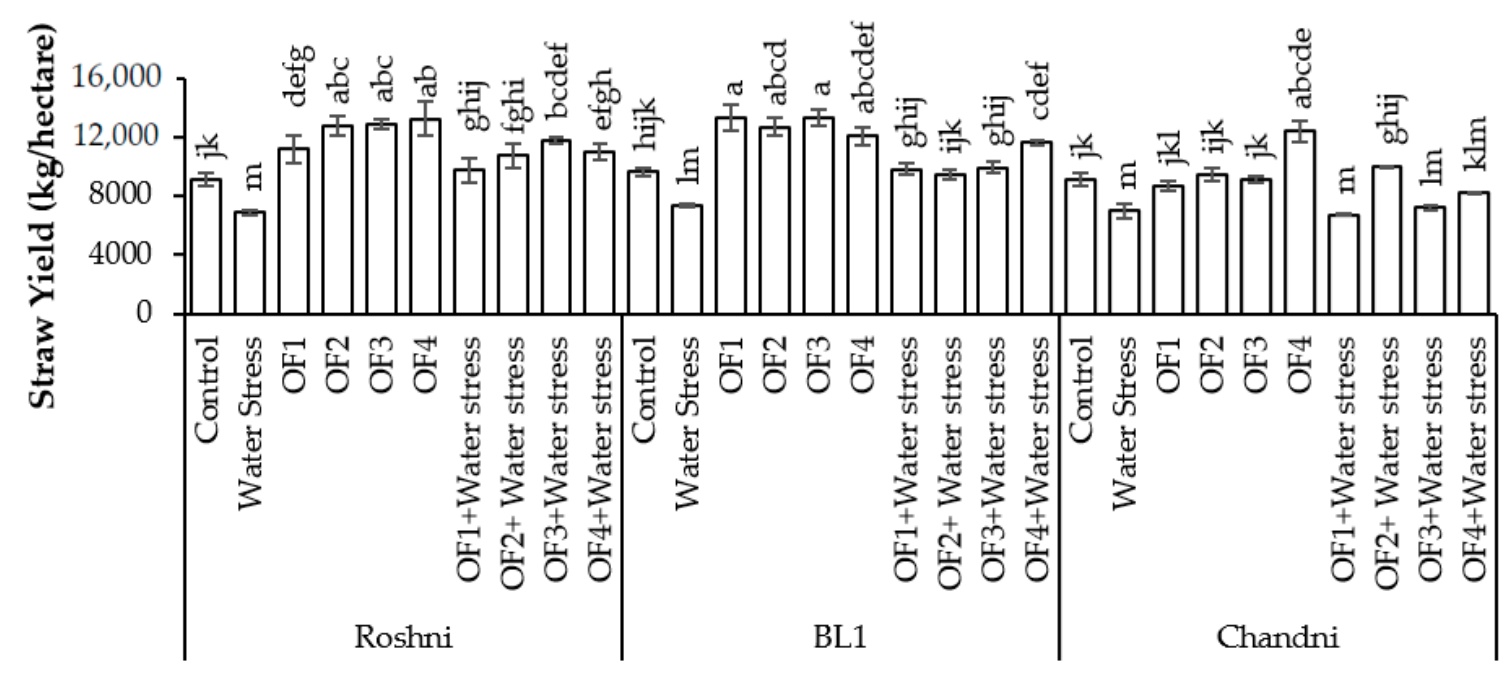

Treatments

Figure 12. Effect of organic fertilizers on straw yield of linseed under water stress conditions. Due to non-significant variations in two years data, we pooled the data together. The different letters above the data columns indicate significant differences among the treatments. OF1—organic fertilizer 1 (1 kg seed cake of Eruca sativa), OF2—organic fertilizer 2 (1 kg seed cake of Eruca sativa $+1 \mathrm{~kg}$ chicken peat), OF3-organic fertilizer 3 (1 kg seed cake of Eruca sativa $+0.5 \mathrm{~kg}$ chicken peat $+0.25 \mathrm{~kg}$ Moringa oleifera leaves $), \mathrm{OF} 4$ - organic fertilizer $4(1 \mathrm{~kg}$ seed cake of Eruca sativa $+0.250 \mathrm{~kg}$ chicken peat $+0.5 \mathrm{~kg}$ Moringa oleifera leaves).

\subsection{Effects of Organic Fertilizers on Fiber Quality of Linseed}

Water stress exhibited a major decrease in fiber length of linseed varieties (Figure 13). Percent decrease in fiber length due to water deficit stress was greater in BL1 $(32.7 \%)$ than Chandni (22.40\%) and Roshni (19.15\%) as compared with their respective untreated and irrigated controls. Linseed plants supplemented with organic fertilizers had a significantly higher fiber length over the control both under normal and water deficit conditions. Under non-stress conditions, OF4 increased fiber length (30.8\% and $22.67 \%)$ of Roshni and Chandni, respectively. However, BL1 showed greater response to OF3 that caused a $27.5 \%$ increase in their fiber length over untreated control. We noted that organic fertilizers completely overcame the negative effects of water deficit stress on fiber length.

Fiber weight was decreased in all the three varieties of linseed upon exposure to water deficit stress (Figure 14). Percent decrease in fiber weight due to water deficit stress was greater in BL1 (50.51\%) than Roshni (37.67\%) and Chandni (35.08\%) as compared with their respective untreated and irrigated controls. Under non-stressed conditions, organic fertilizer OF4 resulted in higher value $(35.4 \%)$ of fiber weight over other treatments. Similarly, decrease in fiber weight after water deficit stress was overcome by all the formulations of organic fertilizer; however, the OF4 was significantly more effective in the protection of fiber weight from the damaging effects of water deficit stress. 


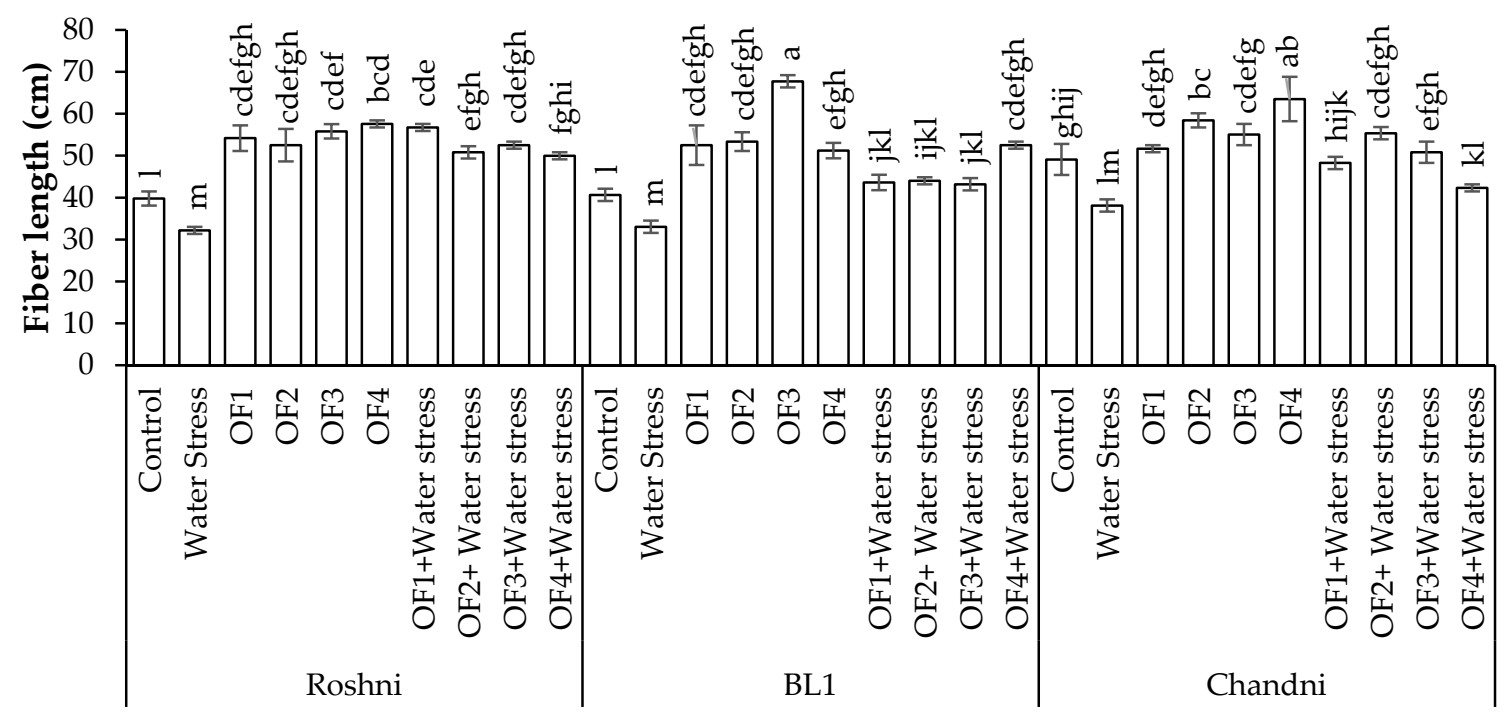

Treatments

Figure 13. Effect of organic fertilizers on fiber length of linseed under water stress conditions. Due to non-significant variations in two years data, we pooled the data together. The different letters above the data columns indicate significant differences among the treatments. OF1—organic fertilizer 1 (1 kg seed cake of Eruca sativa), OF2—organic fertilizer 2 (1 kg seed cake of Eruca sativa $+1 \mathrm{~kg}$ chicken peat), OF3-organic fertilizer 3 (1 kg seed cake of Eruca sativa $+0.5 \mathrm{~kg}$ chicken peat $+0.25 \mathrm{~kg}$ Moringa oleifera leaves $),$ OF4—organic fertilizer $4(1 \mathrm{~kg}$ seed cake of Eruca sativa $+0.250 \mathrm{~kg}$ chicken peat $+0.5 \mathrm{~kg}$ Moringa oleifera leaves).

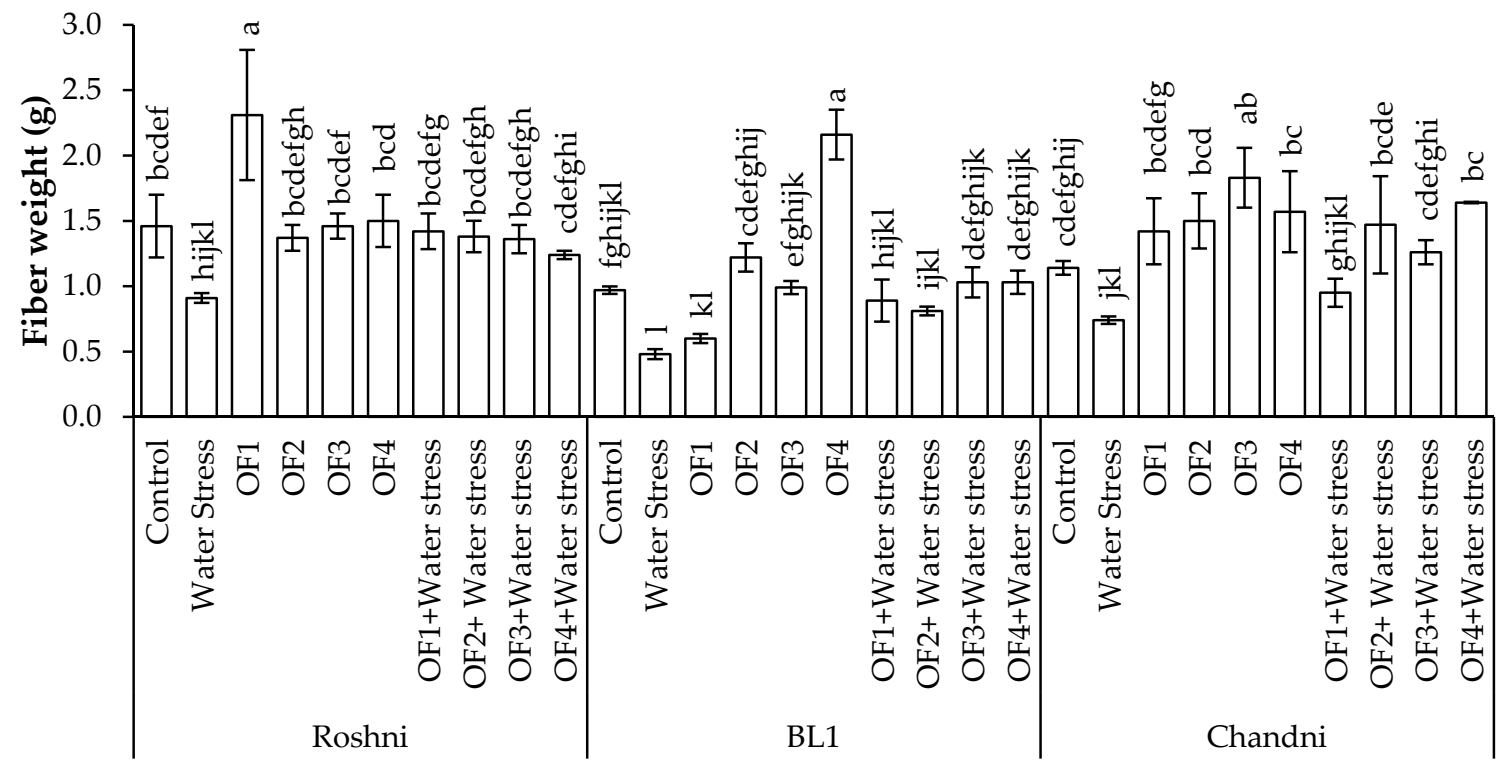

Treatments

Figure 14. Effect of organic fertilizers on fiber weight per plant of linseed under water stress conditions. Due to nonsignificant variations in two years data, we pooled the data together. The different letters above the data columns indicate significant differences among the treatments. OF1—organic fertilizer 1 (1 kg seed cake of Eruca sativa), OF2—organic fertilizer 2 (1 kg seed cake of Eruca sativa $+1 \mathrm{~kg}$ chicken peat), OF3-organic fertilizer 3 (1 kg seed cake of Eruca sativa $+0.5 \mathrm{~kg}$ chicken peat $+0.25 \mathrm{~kg}$ Moringa oleifera leaves), OF4—organic fertilizer 4 (1 kg seed cake of Eruca sativa $+0.250 \mathrm{~kg}$ chicken peat $+0.5 \mathrm{~kg}$ Moringa oleifera leaves). 


\subsection{Pearson Correlation for Growth Parameters of Linseed}

Plant height exhibited significantly positive relationship with fiber length $(\mathrm{r}=0.575)$, fiber weight $(r=0.6061)$, seeds per capsule $(r=0.6444)$, number of capsules per plant $(r=0.3979)$, number of tillers plant ${ }^{-1}(r=0.62390)$, seed yield $(r=0.4937)$, straw yield $(\mathrm{r}=0.4297)$ and thousand seed weight $(\mathrm{r}=0.7229)$. Seed yield had significantly positive correlation with number of seeds per capsule $(r=0.3941)$, number of capsules per plant $(r=0.5020)$, number of tillers per plant $(r=0.5323)$, straw yield $(r=0.8578)$ and 1000 seed weight $(r=0.9290)$. Values of Pearson correlation revealed that correlation of fiber length was significantly positive with fiber weight $(r=0.5329)$ (Table 3$)$.

Table 3. Correlations of growth and yield parameters of Linseed.

\begin{tabular}{lllllllll}
\hline Attributes & FL & FW & NCP & NSC & NT & PH & RWC & SY \\
\hline FW & $0.5329^{* *}$ & & & & & & \\
NCP & $0.589^{* *}$ & $0.255^{*}$ & & & & & \\
NSC & $0.341^{* *}$ & $0.429^{* *}$ & $0.355^{* *}$ & & & & \\
NT & $0.691^{* *}$ & $0.393^{* *}$ & $0.723^{* *}$ & $0.568^{* *}$ & & & \\
PH & $0.576^{* *}$ & $0.606^{* *}$ & $0.398^{* *}$ & $0.644^{* *}$ & $0.624^{* *}$ & & & \\
RWC & 0.005 & -0.0195 & 0.153 & 0.1688 & 0.0511 & 0.082 & & \\
SY & $0.437^{* *}$ & $0.2504^{*}$ & $0.502^{* *}$ & $0.394^{* *}$ & $0.532^{* *}$ & $0.444^{* *}$ & 0.191 & \\
STY & $0.515^{* *}$ & $0.2501^{*}$ & $0.616^{* *}$ & $0.480^{* *}$ & $0.616^{* *}$ & $0.4297^{* *}$ & $0.282^{* *}$ & $0.858^{* *}$ \\
1000 SW & $0.428^{* *}$ & $0.531^{* *}$ & $0.226^{*}$ & $0.379^{* *}$ & $0.449^{* *}$ & $0.723^{* *}$ & -0.09 & 0.0095 \\
\hline
\end{tabular}

Level of significance at $5 \%$ probability. ${ }^{*}=$ significance at $p<0.05$, highly significant ${ }^{* *}=p<0.01$. FW: fiber weight, FL: fiber length, NSC: number of seed per capsule, NCP: number of capsules per plant, NT: number of tillers, PH: plant height, RWC: relative water content, SY: seed yield, STY: straw yield, 1000 SW: thousand seed weight.

\section{Discussion}

We characterized the various organic fertilizers for NPK content with varying values of seed cake of Eruca sativa, chicken peat and M. oleifera leaves. Looking into NPK ratings on organic fertilizers is an important indicator to decide whether the formulated organic fertilizers are suitable or not for soil and plants [22]. Nitrogen is necessary for better plant growth with healthy stems and leaves. Phosphorus is necessary for better establishment of the root system. Whereas, potassium adds in better water flow inside the plants and is necessary for flowering and fruit set $[55,56]$. In present study highest level of $\mathrm{N}$ was recorded in OF4 whereas $\mathrm{P}$ and $\mathrm{K}$ content were higher in OF3. The variations in the content of NPK among the formulated organic fertilizers may be due to alterations in the content of chicken peat and $M$. oleifera leaves. The values of N, P and $\mathrm{K}$ were higher than those reported by Eroa [22] for various formulations of organic fertilizers produced from Jatropha curcas seeds and chicken manure. Maximum value of organic matter was recorded for OF3 followed by OF4. Organic matter plays an important role in the retention of soil moisture. Soil enriched with organic matter has greater water retention potential $[57,58]$.

We found that organic fertilizers OF2 and OF3 had higher EC values than OF1 and OF4. Organic fertilizers of higher EC values may cause soil salinization if applied in larger quantities [59]. Therefore, such organic fertilizers with high EC values may be used with great care for preventing soil salinization [60].

Our studies pointed out that organic fertilizers improved soil fertility status, measured as total soil N, available $\mathrm{P}, \mathrm{K}, \mathrm{Zn}$ and Fe contents after two months of their application. Increase in soil total $\mathrm{N}$ due to application of organic fertilizers has been reported previously by Angelova et al. [61]. Higher soil organic matter content and acidic $\mathrm{pH}$ favors the availability of $\mathrm{N}$ for plants [62]. Improvement in soil $\mathrm{P}$ occurs due to the application of organic compost [63] largely due to improved microbial activity [64]. Our synthesized fertilizers OF3 and OF4 contained Moringa oleifera leaves along with E. sativa seed cake and chicken peat. Organic fertilizers OF1 and OF2 did not contain Moringa oleifera leaves. This has led us to the conclusion that addition of Moringa oleifera leaves has improved soil fertility potential of the synthesized organic fertilizers. 
The organic fertilizers application increased soil EC by decreasing soil $\mathrm{pH}$. Electrical conductivity is used as an indicator of total soluble salts present in the soil medium and gives information about salinity. Soils with EC values less than $1 \mathrm{ds} / \mathrm{m}$ are considered as non-saline. Increase in EC value of soil causes a reduction in soil microbial activity and nitrogen cycling [65]. The EC values of soil amended with organic fertilizers were lower than EC range (750 to $3490 \mu \mathrm{S} \mathrm{cm}{ }^{-1}$ ) determined for soil fertility status and plant [66]. However, our synthesized organic fertilizers improved soil EC values under normal growth conditions. Increase in soil EC by organic fertilizers may be due to their high $\mathrm{K}^{+}$content and various inorganic $\mathrm{N}$ ions present in the seed cake of $E$. sativa, chicken peat and $M$. oleifera. The decrease in soil $\mathrm{pH}$ due to organic fertilizers application can be explained by the number of $\mathrm{H}^{+}$ions added to the soil due to generation of inorganic acidic species like $\mathrm{HNO}_{3}$ and $\mathrm{H}_{2} \mathrm{SO}_{4}$ during the decomposition of organic material [67]. Moreover, the alterations in soil $\mathrm{pH}$ are linked with the rate of nitrification, organic acids production and oxidation of various kinds of chemical species during decomposition of organic wastes [68].

In our study, the organic fertilizers prevented decrease in LRWC of linseed. The LRWC is an important indicator of plant water status [69]. Water deficit stress results in a loss of cell turgidity resulting in a decrease in gaseous exchange by closing of stomata. Our findings established that organic fertilizers improved the water holding capacity of soil which ultimately maintained normal water supply to plants under water deficit stress. The variations in LRWC of linseed varieties may be due to differences in their genetic makeup and resistance to water deficit stress. The organic fertilizers were rich in $\mathrm{K}$, which is necessary for normal water flow inside the plant body [56,70]. We found that water deficit stress decreased plant height and number of tillers per plant. Water deficit stress causes decrease in turgor of cell which leads to reduced cell division in growing regions of plants [71]. However, the organic fertilizers minimized water deficit stress induced decrease in plant height and production of tillers. This may be due to the fact that our formulated organic fertilizers were rich in nitrogen and phosphorus. Presence of sufficient amounts of nitrogen and phosphorus in soil results in taller and healthy plants [72].

In response to low soil moisture availability linseed plants produced high concentration of phenolic compounds in roots and leaves. The plant roots and the microbial community influence each other [73]. In the control and water stress treatments organic fertilizers raised the phenolics level. Higher production of phenolic compounds is an adaptive mechanism of plants to low soil moisture [74]. Phenolic compounds function as antioxidants to stabilize reactive oxygen species and increase the thickness of cell walls to prevent water loss from cells $[30,75]$. Beneficial effects of organic fertilizers on phenolic compounds in plants have been reported [76]. Our proposed organic fertilizers OF3 and OF4 have $M$. oleifera leaves as a component which is also reported for positive effects on phenolic compounds in maize plants [77]. It is generally accepted that higher production of phenolic compounds occur in water deficit conditions at the cost of photosynthates which results in lower dry mass production of plants [78]. In our study, it was noted that our proposed organic fertilizers not only improved the content of phenolics but also seed and straw yield in linseed. This dual effect of organic fertilizers can be correlated to its phytochemical's makeup and their effect on endogenous hormones.

The yield parameters like number of capsules per plants, number of seeds capsule ${ }^{-1}$, 1000 seed weight and total seed yield was decreased by water deficit stress. Several authors have reported yield lessening in linseed due to water stress [79,80]. Our formulated organic fertilizers particularly OF3 and OF4 prevented losses in seed yield caused by water stress. This may be credited to the fact that organic fertilizers improved not only water holding capacity of soil but also improved total $\mathrm{N}$, available $\mathrm{P}$ and $\mathrm{K}$ content of the soil. Our formulated organic fertilizers improved seed length and width and thus resulted in healthy seeds.

Reduction in straw yield of linseed varieties was recorded due to water deficit stress. Dry season with decrease in irrigation intervals resulted in a reduction of straw yield in linseed [81]. Our formulated organic fertilizers OF3 and OF4 prevented losses in straw 
yield due to water deficit stress. The higher straw yield in plots supplemented with organic fertilizers may be partly accounted due to availability of sufficient soil moisture and nitrogen content in such plots which resulted in secondary growth and biomass partitioning in favor of stems [82]. Moreover, linseed is a crop in which the root system is severely affected by water deficiency in soil and produces shallow roots [83].

Fiber quality measured as fiber length and weight was decreased by water deficit stress. However, our prepared organic fertilizers not only improved fiber quality under nonstress but also under water deficit stress. Decrease in fiber yield due to low availability of soil moisture is common in linseed [84]. Organic fertilizers improved nitrogen, phosphorus and potassium availability to the linseed plants which ultimately led to improved fiber quality. The beneficial effect of the sufficient availability of soil nitrogen on fiber quality and yield of linseed has been reported [85]. Kumar et al. [86] found encouraging effects of vermicomposting on fiber length and weight of linseed.

\section{Conclusions}

Our prepared organic fertilizers particularly OF3 and OF4 were rich sources of NPK, $\mathrm{Zn}, \mathrm{Fe}$ and organic matter, improved soil fertility and resulted in a better establishment of linseed crop. The water deficit stress has a reducing effect on linseed growth, yield and fiber quality. It is worthy to note that our prepared organic fertilizers OF3 and OF4 were highly and nearly equally effective in improving growth, yield and fiber quality of linseed both under control and water stress environments. The potential of OF3 and OF4 as potent nutrient careers can be explored to enhance and improve linseed production, soil nutrients status and water retention capacity.

Author Contributions: Conceptualization, A.U.K.; methodology, A.U.K.; formal analysis, N.K., F.U. and S.M.; investigation, A.U.K.; resources, I.I., I.A.A. and S.S.; data curation, N.K., Z.A.K., S.M.K. and G.S.H.; writing-original draft preparation, A.U.K., F.U., S.M., S.F. and S.D.; writing-review and editing, S.F., S.D., R.D., I.I., I.A.A., H.M.A. and M.H.S.; funding acquisition, I.A.A. All authors have read and agreed to the published version of the manuscript.

Funding: Researchers Supporting Project number (RSP-2020/176), King Saud University, Riyadh, Saudi Arabia.

Institutional Review Board Statement: Not applicable.

Informed Consent Statement: Not applicable.

Data Availability Statement: The data presented in this study are available on request from the corresponding author. The data are not publicly available due to privacy.

Acknowledgments: The authors would like to extend their sincere appreciation to the Researchers Supporting Project number (RSP-2020/176), King Saud University, Riyadh, Saudi Arabia. The authors thank Department of Botany University of Science and Technology Bannu KP, Pakistan for provision of research facilities

Conflicts of Interest: The authors declare no conflict of interest.

\section{References}

1. Mahmood, F.; Khan, I.; Ashraf, U.; Shahzad, T.; Hussain, S.; Shahid, M.; Abid, M.; Ullah, S. Effects of organic and inorganic manures on maize and their residual impact on soil physico-chemical properties. J. Soil Sci. Plant Nutr. 2017, 17, 22-32. [CrossRef]

2. Lan, H.X.; Xia, J.G. Absorption and Accumulation of Lead and Cadmium in Mengshan Tea Plant. J. Agro Environ. Sci. 2008, 27, 1077-1083.

3. Ullah, M.A.; Aamir, S.S.; Haider, H.; Adil, B. Growth of olive varieties in tunnel under salinity plus humic acid, biozote and vermicompost. Int. J. Adv. Res. Biol. Sci. 2018, 5, 118-124.

4. Yadav, S.K.; Babu, S.; Yadav, M.K.; Singh, K.; Yadav, G.S.; Pal, S. A Review of Organic Farming for Sustainable Agriculture in Northern India. Int. J. Agron. 2013, 2013, 1-8. [CrossRef]

5. Mamia, A.; Amin, A.; Roy, T.S.; Faruk, G.M. Influence of inorganic and organic fertilizers on growth and yield of soybean. Bangladesh Agron. J. 2018, 21, 77-81. [CrossRef]

6. Zhu, N.; Tan, X.; Li, M.; Pan, X.; Shi, Q. Effects of different organic fertilizers on growth of rice seedlings raised in straw substrates. Acta Agric. Univ. Jiangxiensis 2018, 40, 286-294. 
7. Dittmar, H.; Drach, M.; Vosskamp, R.; Trenkel, M.E.; Gutser, R.; Steffens, G. Fertilizers, 2. Types. In Ullmann's Encyclopedia of Industrial Chemistry; Wiley-VCH Verlag GmbH \& Co. KGaA: Weinheim, Germany, 2009.

8. Timsina, J. Can Organic Sources of Nutrients Increase Crop Yields to Meet Global Food Demand? Agronomy 2018, 8, 214. [CrossRef]

9. Palm, C.A.; Gachengo, C.N.; Delve, R.J.; Cadisch, G.; Giller, K.E. Organic inputs for soil fertility management in tropical agroecosystems: Application of an organic resource database. Agric. Ecosyst. Environ. 2001, 83, 27-42. [CrossRef]

10. Kamran, M.A.; Jiang, J.; Li, J.; Shi, R.; Mehmood, K.; Baquy, M.A.-A.; Xu, R. Amelioration of soil acidity, Olsen-P, and phosphatase activity by manure- and peat-derived biochars in different acidic soils. Arab. J. Geosci. 2018, 11, 272. [CrossRef]

11. Zafar-ul-Hye, M.; Danish, S.; Khan, M.J.; Fahad, S.; Datta, R.; Brtnicky, M.; Kintl, A.; Hussain, M.S.; El-Esaw, M.A.; Naeem, M. Effect of Cadmium-Tolerant Rhizobacteria on Growth Attributes and Chlorophyll Contents of Bitter Gourd under Cadmium Toxicity. Plants 2020, 9, 1386. [CrossRef]

12. Zafar-ul-Hye, M.; Tahzeeb-ul-Hassan, M.; Abid, M.; Fahad, S.; Brtnicky, M.; Dokulilova, T.; Datta, R.; Danish, S. Potential role of compost mixed biochar with rhizobacteria in mitigating lead toxicity in spinach. Sci. Rep. 2020, 10, 69183. [CrossRef] [PubMed]

13. Zafar-ul-Hye, M.; Danish, S.; Fahad, S.; Datta, R.; Abbas, M.; Rahi, A.A.; Brtnicky, M.; Holátko, J.; Tarar, Z.H.; Nasir, M. Alleviation of Cadmium Adverse Effects by Improving Nutrients Uptake in Bitter Gourd through Cadmium Tolerant Rhizobacteria. Environments 2020, 7, 54. [CrossRef]

14. Adnan, M.; Fahad, S.; Zamin, M.; Shah, S.; Mian, I.A.; Danish, S.; Zafar-ul-Hye, M.; Battaglia, M.L.; Naz, R.M.M.; Saeed, B.; et al. Coupling Phosphate-Solubilizing Bacteria with Phosphorus Supplements Improve Maize Phosphorus Acquisition and Growth under Lime Induced Salinity Stress. Plants 2020, 9, 900. [CrossRef] [PubMed]

15. Danish, S.; Zafar-ul-Hye, M.; Fahad, S.; Saud, S.; Brtnicky, M.; Hammerschmiedt, T.; Datta, R. Drought Stress Alleviation by ACC Deaminase Producing Achromobacter xylosoxidans and Enterobacter cloacae, with and without Timber Waste Biochar in Maize. Sustainability 2020, 12, 6286. [CrossRef]

16. Abbas, M.; Anwar, J.; Zafar-ul-Hye, M.; Khan, R.I.; Saleem, M.; Rahi, A.A.; Danish, S.; Datta, R. Effect of Seaweed Extract on Productivity and Quality Attributes of Four Onion Cultivars. Horticulturae 2020, 6, 28. [CrossRef]

17. Shafi, M.I.; Adnan, M.; Fahad, S.; Wahid, F.; Khan, A.; Yue, Z.; Danish, S.; Zafar, M.; Brtnicky, M.; Datta, R. Application of single superphosphate with humic acid improves the growth, yield and phosphorus uptake of wheat (Triticum aestivum L.) in calcareous soil. Agronomy 2020, 10, 1224. [CrossRef]

18. Ullah, A.; Ali, M.; Shahzad, K.; Ahmad, F.; Iqbal, S.; Rahman, M.H.U.; Ahmad, S.; Iqbal, M.M.; Danish, S.; Fahad, S. Impact of Seed Dressing and Soil Application of Potassium Humate on Cotton Plants Productivity and Fiber Quality. Plants 2020, 9 , 1444. [CrossRef]

19. Zarei, T.; Danish, S. Effect of micronutrients foliar supplementation on the production and eminence of plum (Prunus domestica L.). Qual. Assur. Saf. Crop. Foods 2020, 12, 32-40. [CrossRef]

20. Rafiullah, R.; Khan, M.J.; Muhammad, D.; Fahad, S.; Adnan, M.; Wahid, F.; Alamri, S.; Khan, F.; Dawar, K.; Irshad, I.; et al. Phosphorus Nutrient Management through Synchronization of Application Methods and Rates in Wheat and Maize Crops. Plants 2020, 9, 1389. [CrossRef]

21. Bot, A.; Benites, J. The Importance of Soil Organic Matter: Key to Drought-Resistant Soil and Sustained Food Production; Food \& Agriculture Org.: Rome, Italy, 2005.

22. Eroa, M.G. Production and characterization of organic fertilizer from Tubang-Bakod (Jatropha Curcas) seed cake and chicken manure. Asia Pacific J. Multidiscip. Res. 2015, 3, 9-13.

23. Tejada, M.; Garcia, C.; Gonzalez, J.L.; Hernandez, M.T. Use of organic amendment as a strategy for saline soil remediation: Influence on the physical, chemical and biological properties of soil. Soil Biol. Biochem. 2006, 38, 1413-1421. [CrossRef]

24. Vengadaramana, A.; Jashothan, P.T.J. Effect of organic fertilizers on the water holding capacity of soil in different terrains of Jaffna peninsula in Sri Lanka. J. Nat. Prod. Plant Resour. 2012, 2, 500-503.

25. Gould, C.M. Compost increases water holding capacity of droughty soils. Michigan State Univ. Ext. 2015.

26. Zhen, Z.; Liu, H.; Wang, N.; Guo, L.; Meng, J.; Ding, N.; Wu, G.; Jiang, G. Effects of manure compost application on soil microbial community diversity and soil microenvironments in a temperate cropland in China. PLoS ONE 2014, 9, e108555. [CrossRef]

27. Bargaz, A.; Lyamlouli, K.; Chtouki, M.; Zeroual, Y.; Dhiba, D. Soil Microbial Resources for Improving Fertilizers Efficiency in an Integrated Plant Nutrient Management System. Front. Microbiol. 2018, 9, 1606. [CrossRef]

28. Sehgal, A.; Sita, K.; Siddique, K.H.M.; Kumar, R.; Bhogireddy, S.; Varshney, R.K.; HanumanthaRao, B.; Nair, R.M.; Prasad, P.V.V.; Nayyar, H. Drought or/and Heat-Stress Effects on Seed Filling in Food Crops: Impacts on Functional Biochemistry, Seed Yields, and Nutritional Quality. Front. Plant Sci. 2018, 9, 1705. [CrossRef]

29. Fahad, S.; Chen, Y.; Saud, S.; Wang, K.; Xiong, D.; Chen, C.; Wu, C.; Shah, F.; Nie, L.; Huang, J. Ultraviolet radiation effect on photosynthetic pigments, biochemical attributes, antioxidant enzyme activity and hormonal contents of wheat. J. Food Agric. Environ. 2013, 11, 1635-1641.

30. Latif, M.; Akram, N.A.; Ashraf, M. Regulation of some biochemical attributes in drought-stressed cauliflower (Brassica oleracea L.) by seed pre-treatment with ascorbic acid. J. Hortic. Sci. Biotechnol. 2016, 91, 129-137. [CrossRef]

31. Singh, K.K.; Mridula, D.; Rehal, J.; Barnwal, P. Flaxseed: A Potential Source of Food, Feed and Fiber. Crit. Rev. Food Sci. Nutr. 2011, 51, 210-222. [CrossRef] 
32. Shim, Y.Y.; Gui, B.; Wang, Y.; Reaney, M.J.T. Flaxseed (Linum usitatissimum L.) oil processing and selected products. Trends Food Sci. Technol. 2015, 43, 162-177. [CrossRef]

33. Ullah, F.; Bano, A.; Ali, S. Optimization Of Protocol For Biodiesel Production Of Linseed (Linum Usitatissimum L.) Oil. Pol. J. Chem. Technol. 2013, 15, 74-77. [CrossRef]

34. El-Beltagi, H.S.; Salama, Z.A.; El-Hariri, D.M. Evaluation of fatty acids profile and the content of some secondary metabolites in seeds of different flax cultivars (Linum usitatissimum L.). Gen. Appl. Plant Physiol. 2007, 33, 187-202.

35. Dhirhi, N.; Shukla, R.; Patel, N.B.; Sahu, H.; Mehta, N. Extraction method of flax fibre and its uses. Plant Arch. 2015, 15, 711-716.

36. Dohat, M.; Patel, R.A.; Patel, V.Y.; Patel, H.K. Effect of Irrigation and Nitrogen on Growth and Yield of linseed (Linum usitatissimum L.). J. Pure Appl. Microbiol. 2017, 11, 949-951. [CrossRef]

37. Bauer, P.J.; Stone, K.C.; Foulk, J.A.; Dodd, R.B. Irrigation and cultivar effect on flax fiber and seed yield in the Southeast USA. Ind. Crops Prod. 2015, 67, 7-10. [CrossRef]

38. Nelson, D.W.; Sommers, L.E. Total carbon, organic carbon, and organic matter. Methods Soil Anal. Part 3 Chem. Methods 1996, 5, 961-1010.

39. Rashid, A. Mapping Zinc Fertility of Soils Using Indicator Plants and Soil Analyses. Ph.D. Thesis, University of Hawaii, Hawaii, HI, USA, August 1986.

40. Ryan, P.R.; Delhaize, E.; Jones, D.L. Function and mechanism of organic anionexudation from plantroots. Annu. Rev. Plant Physiol. Plant Mol. Biol. 2001, 52, 527-560. [CrossRef]

41. Shimizu, A.; Abe, S. Verification of Performance Characteristics of Testing Method for Citrate-Soluble Phosphorus Content by Ammonium Vanadomolybdate Absorption Photometry. Res. Rep. Fertil. 2012, 5, 180-189.

42. Bremner, M. Chapter 37, Nitrogen-Total. In Methods of Soil Analysis Part 3. Chem. Methods-SSSA B. Ser. 5; American Society of Agronomy: Madison, WI, USA, 1996; pp. 1085-1121.

43. Walkley, A. A critical examination of a rapid method for determining organic carbon in soils-Effect of variations in digestion conditions and of inorganic soil constituents. Soil Sci. 1947, 63, 251-264. [CrossRef]

44. Bouyoucos, G.J. Hydrometer Method Improved for Making Particle Size Analyses of Soils 1. Agron. J. 1962, 54, 464-465. [CrossRef]

45. Soltanpour, P.N.; Workman, S. Modification of the NH4 HCO3-DTPA soil test to omit carbon black. Commun. Soil Sci. Plant Anal. 1979, 10, 1411-1420. [CrossRef]

46. Bremner, J.M.; Mulvaney, C.S. Nitrogen-total. In Methods of Soil Analysis, Part 2. Chemical and Microbiological Properties, 2nd ed.; Page, A.L., Miller, R.H., Keeney, D.R., Eds.; American Society of Agronomy: Madison, WI, USA, 1982; pp. 595-624.

47. Olsen, S.R.; Sommers, L.E. Phosphorus. In Methods of Soil Analysis Part 2 Chemical and Microbiological Properties; Page, A.L., Ed.; American Society of Agronomy: Madison, WI, USA, 1982; pp. 403-430.

48. McLean, E.O. Soil pH and lime requirement. In Methods of Soil Analysis Part 2 Chemical and Microbiological Properties; American Society of Agronomy: Madison, WI, USA, 1982; pp. 199-224.

49. Erdoğdu, Y.; Yaver, S.; Onemli, F. The Effect of Different Seeding Rates on Grain Yield and Yield Components in SomeFlax (Linumusitatissimum L.) Varieties. Int. J. Environ. Agric. Res. 2018, 4, 1-9.

50. Husain, K.; Dubey, S.D.; Singh, D.; Srivastava, R.L. Effect of nutrient management on yield, economics and nutrient status of soil in maize-linseed cropping system. J. Pharmacogn. Phytochem. 2017, 6, 327-330.

51. Gao, J.F. Experimental Technology in Plant Physiology; World Map and Book Press: Xi'an, China, 2000; pp. 101-103.

52. Shen, Y.; Jin, L.; Xiao, P.; Lu, Y.; Bao, J. Total phenolics, flavonoids, antioxidant capacity in rice grain and their relations to grain color, size and weight. J. Cereal Sci. 2009, 49, 106-111. [CrossRef]

53. Ma, D.; Li, Y.; Zhang, J.; Wang, C.; Qin, H.; Ding, H.; Xie, Y.; Guo, T. Accumulation of Phenolic Compounds and Expression Profiles of Phenolic Acid Biosynthesis-Related Genes in Developing Grains of White, Purple, and Red Wheat. Front. Plant Sci. 2016, 7, 528. [CrossRef]

54. Steel, R.G.; Torrie, J.H.; Dickey, D.A. Principles and Procedures of Statistics: A Biometrical Approach, 3rd ed.; McGraw Hill Book International Co.: Singapore, 1997.

55. Ahmad, P.; Abdel Latef, A.A.; Abd-Allah, E.F.; Hashem, A.; Sarwat, M.; Anjum, N.A.; Gucel, S. Calcium and potassium supplementation enhanced growth, osmolyte secondary metabolite production, and enzymatic antioxidant machinery in cadmium-exposed chickpea (Cicer arietinum L.). Front. Plant Sci. 2016, 7, 513. [CrossRef]

56. Hasanuzzaman, M.; Bhuyan, M.; Nahar, K.; Hossain, M.; Mahmud, J.; Hossen, M.; Masud, A.; Moumita, M.; Fujita, M. Potassium: A Vital Regulator of Plant Responses and Tolerance to Abiotic Stresses. Agronomy 2018, 8, 31. [CrossRef]

57. Liyanage, T.D.P.; Leelamanie, D.A.L. Influence of organic manure amendments on water repellency, water entry value, and water retention of soil samples from a tropical Ultisol. J. Hydrol. Hydromech. 2016, 64, 160-166. [CrossRef]

58. Miller, V.S.; Naeth, M.A. Hydrogel and Organic Amendments to Increase Water Retention in Anthroposols for Land Reclamation. Appl. Environ. Soil Sci. 2019, 2019, 1-11. [CrossRef]

59. Melo, L.C.A.; Silva, C.A.; Dias, B.D.O. Characterization of the organic matrix of residues from different origins. Rev. Bras. Ciência Solo 2008, 32, 101-110. [CrossRef]

60. Higashikawa, F.S.; Silva, C.A.; Bettiol, W. Chemical and physical properties of organic residues. Rev. Bras. Ciência Solo 2010, 34, 1742-1752. [CrossRef]

61. Angelova, V.R.; Akova, V.I.; Artinova, N.S.; Ivanov, K.I. The effect of organic amendments on soil chemical characteristics. Bulg. J. Agric. Sci. 2013, 19, 958-971. 
62. Zupanc, V.; Justin, M.Z. Changes in soil characteristics during landfill leachate irrigation of Populus deltoides. Waste Manag. 2010, 30, 2130-2136. [CrossRef] [PubMed]

63. Marinari, S.; Masciandaro, G.; Ceccanti, B.; Grego, S. Influence of organic and mineral fertilisers on soil biological and physical properties. Bioresour. Technol. 2000, 72, 9-17. [CrossRef]

64. Arancon, N.Q.; Edwards, C.A.; Bierman, P. Influences of vermicomposts on field strawberries: Part 2. Effects on soil microbiological and chemical properties. Bioresour. Technol. 2006, 97, 831-840. [CrossRef] [PubMed]

65. Citak, S.; Sonmez, S. Effects of chemical fertilizer and different organic manure application on soil pH, EC and organic matter content. J. Food Agric. Environ. 2011, 9, 739-741.

66. Carmo, D.L.; Lima, L.B.; Silva, C.A. Soil Fertility and Electrical Conductivity Affected by Organic Waste Rates and Nutrient Inputs. Rev. Bras. Ciência Solo 2016, 40, 40. [CrossRef]

67. Galdos, M.V.; Maria, D.E.I.C.; Camargo, O.A. Chemical attributes and corn production in an eutrophic red latosol treated with sewage sludg. Braz. J. Soil Sci. 2004, 23, 569-577.

68. Mokolobate, M.S.; Haynes, R.J. Increases in $\mathrm{pH}$ and soluble salts influence the effect that additions of organic residues have on concentrations of exchangeable and soil solution aluminium. Eur. J. Soil Sci. 2002, 53, 481-489. [CrossRef]

69. Jaleel, C.A.; Manivannan, P.; Wahid, A.M.; Farooq, H.J.; Al-Juburi, R.; Somasundaram, R.P. Drought Stress in Plants: A Review on Morphological Characteristics and Pigments Composition. Int. J. Agric. Biol. 2009, 11, 100-105.

70. Soremi, A.; Adetunji, M.; Adejuyigbe, C.; Bodunde, J.; Azeez, J. Influence of Organic Manure on Phosphorus and Potassium Fractions in Soil Planted with Soybean. Int. J. Plant Soil Sci. 2017, 14, 1-11. [CrossRef] [PubMed]

71. Farooq, M.; Wahid, A.; Kobayashi, N.; Fujita, D.; Basra, S.M.A. Plant drought stress: Effects, mechanisms and management. Agron. Sustain. Dev. 2009, 29, 185-212. [CrossRef]

72. Razaq, M.; Zhang, P.; Shen, H.-L. Salahuddin Influence of nitrogen and phosphorous on the growth and root morphology of Acer mono. PLoS ONE 2017, 12, e0171321. [CrossRef] [PubMed]

73. Pathan, S.I.; Větrovský, T.; Giagnoni, L.; Datta, R.; Baldrian, P.; Nannipieri, P.; Renella, G. Microbial expression profiles in the rhizosphere of two maize lines differing in N use efficiency. Plant Soil 2018, 433, 401-413. [CrossRef]

74. Hale, B.K.; Herms, D.A.; Hansen, R.C.; Clausen, T.P.; Arnold, D. Effects of Drought Stress and Nutrient Availability on Dry Matter Allocation, Phenolic Glycosides, and Rapid Induced Resistance of Poplar to Two Lymantriid Defoliators. J. Chem. Ecol. 2005, 31, 2601-2620. [CrossRef]

75. Hura, T.; Hura, K.; Ostrowska, A.; Grzesiak, M.; Dziurka, K. The cell wall-bound phenolics as a biochemical indicator of soil drought resistance in winter triticale. Plant Soil Environ. 2013, 59, 189-195. [CrossRef]

76. Zhang, E.; Duan, Y. Effects of Long-term Nitrogen and Organic Fertilization on Antioxidants Content of Tomato Fruits. J. Hortic. 2016, 3. [CrossRef]

77. Pervez, K.; Ullah, F.; Mehmood, S.; Khattak, A. Effect of Moringa oleifera Lam. leaf aqueous extract on growth attributes and cell wall bound phenolics accumulation in maize (Zea mays L.) under drought stress. Kuwait J. Sci. 2017, 44, 110-118.

78. Hura, K.; Ostrowska, A.; Dziurka, K.; Hura, T. Photosynthetic apparatus activity in relation to high and low contents of cell wall-bound phenolics in triticale under drought stress. Photosynthetica 2017, 55, 698-704. [CrossRef]

79. Mirshekari, M.; Amiri, R.; Nezha, H.A.I.; Sadat, N.S.R.; Zandvak, O. Effects of Planting Date and Low Irrigation on Quantitative and Qualitative Traits of Flax Seed. Res. J. Agron. 2012, 6, 20-31. [CrossRef]

80. Sadak, M.S. Physiological role of trehalose on enhancing salinity tolerance of wheat plant. Bull. Natl. Res. Cent. 2019, 43, 53. [CrossRef]

81. Gabiana, C.; McKenzie, B.A.; Hill, G.D. The influence of plant population, nitrogen and irrigation on yield and yield components of linseed. Agron. N. Z. 2005, 35, 44-56.

82. Sankari, H.S. Linseed (Linum usitatissimum L.) Cultivars and Breeding Lines as Stem Biomass Producers. J. Agron. Crop Sci. 2000, 184, 225-231. [CrossRef]

83. Hocking, P.J.; Keerthisinghe, G.; Smith, F.W.; Randall, P.J. Comparison of the ability of different crop species to access poorlyavailable soil phosphorus. Plant Nutr. Sustain. Food Prod. Environ. 1997, 305-308. [CrossRef]

84. Patel, R.K.; Tomar, G.S.; Dwivedi, S.K. Effect of irrigation scheduling and nitrogen levels on growth, yield and water productivity of linseed (Linum usitatissimum L.) under Vertisols. J. Appl. Nat. Sci. 2017, 9, 698-705. [CrossRef]

85. El-Shimy, G.H.; Mostafa, S.H.A.; Abd El-Dayem, M.A. Effect of NPK fertilizer levels on yield and its components of some flax genotypes. Ann. Agric. Sci. Moshtohor 2002, 40, 6779.

86. Kumar, A.; Pramanick, B.; Mahapatra, B.S.; Singh, S.P.; Shukla, D.K. Growth, yield and quality improvement of flax (Linum usitattisimum L.) grown under tarai region of Uttarakhand, India through integrated nutrient management practices. Ind. Crops Prod. 2019, 140, 111710. [CrossRef] 